\title{
Structured decision analysis informed by traditional ecological knowledge as a tool to strengthen subsistence systems in a changing Arctic
}

\author{
Katherine S. Christie $^{1}$, Tuula E. Hollmen ${ }^{1,2}$, Henry P. Huntington $^{3}$ and James R. Lovvorn ${ }^{4}$
}

\begin{abstract}
Climate change is impacting the subsistence livelihoods of many indigenous communities in the Arctic. We describe how structured decision analysis (SDA), informed by traditional ecological knowledge, can be used to understand the mechanisms of how climate change influences subsistence species and their harvest, and to build upon existing adaptive strategies and decision-making processes. In the Iñupiat community of Wainwright, Alaska, we test SDA as a potential framework by which vulnerabilities of subsistence systems can be identified and climate change adaptations can be prioritized. Over the course of five workshops, participants identified issues of concern, assessed the benefits and trade-offs of different strategies to enhance the safety of subsistence activities, identified factors influencing key subsistence species and their accessibility, and assessed the dependence of animals and their harvest on sea ice. Furthermore, we asked workshop participants to assess whether subsistence resources have increased, decreased, or remained stable over the past decade. Declining caribou populations and unsafe ice conditions for hunters were of particular concern in Wainwright. Participants identified high priority safety strategies such as a new docking facility, safety workshops, a hunter meeting place, and search and rescue boats. Because of its coastal location on a lagoon at the mouth of a river, Wainwright has a highly diverse subsistence system that may in part buffer the negative effects of climate change. Furthermore, most species or groups harvested in Wainwright were assessed as stable or increasing. Nevertheless, of the five most important subsistence species in Wainwright, one experienced recent population declines (caribou) and the harvest of three others depends on the presence of thick, reliable shorefast ice. We propose that SDA can be a useful tool to assess the vulnerability of subsistence systems to climate change, and can be used to prioritize strategies to adapt to climate change.
\end{abstract}

Key Words: adaptive capacity; Arctic; bearded seal; bowhead whale; caribou; climate change; hunting; Inuit; sea ice; structured decision analysis; subsistence; walrus

\section{INTRODUCTION}

Societies worldwide are facing the challenge of both mitigating climate change by reducing carbon emissions and adapting to a suite of environmental changes. Widespread climate-related changes such as coastal erosion, drought, crop failure, and altered hydrological systems are expected to threaten the safety, health, and livelihoods of people at increasing rates (Nelson et al. 2009, Grace et al. 2012, IPCC 2014). The vulnerability of different cultures and individuals is a function of complex factors including exposure, socioeconomic status, and income (Patt et al. 2010, IPCC 2014), and the ability of societies to adapt to changing conditions has increasingly become the focus of policy makers and social scientists (Yohe and Tol 2002, Nelson et al. 2007, Adger et al. 2009, Ford et al. 2010). In the context of human dimensions of climate change, adaptation can be defined as: "a process, action or outcome in a system (household, community, group, sector, region, country) in order for the system to better cope with, manage or adjust to some changing condition, stress, hazard, risk or opportunity" (Smit and Wandel 2006:282). It is generally understood that proactive approaches to adaptation are likely to be more effective than reactive responses (Easterling et al. 2004, Ford et al. 2015). Furthermore, participatory approaches that engage communities at the local level have a higher chance of success than top-down policy interventions. Local level approaches that examine adaptation challenges on a case-by-case basis are more likely to be consistent with the purposes and norms of local cultures. As a result, these initiatives have a greater probability of being embraced by individuals and communities (Newton et al. 2005, Chapin et al. 2006, Cameron 2012).
Structured decision analysis (SDA) provides a framework by which climate change adaptations can be identified and prioritized based on consultations with local communities and expert knowledge holders (Ohlson et al. 2005, Ogden and Innes 2009). This method offers a process to bring stakeholders and decision makers to the table and explores how different decision alternatives can meet or satisfy values-based objectives (Keeney 1982). In the context of SDA, objectives define the things that matter to stakeholders, and identify both what is important and the direction of preference (Ohlson et al. 2005). Objectives can be divided into fundamental, overarching objectives, e.g., maintain a healthy subsistence system into the future, and then broken down into more specific objectives, e.g., maximize the safety of hunting activities under changing conditions. In the context of climate change adaptation, SDA involves the following steps: (1) define the climate change related problems to be addressed, (2) have stakeholders set objectives, (3) identify alternative adaptation strategies, (4) predict the effectiveness of each adaptation strategy (this is often done by eliciting expert opinion), (5) choose a strategy that achieves an acceptable balance among objectives, (6) implement the decision and monitor the effectiveness of strategies, and (7) modify the adaptation strategy if the chosen alternative does not adequately meet the objectives (Fig. 1; Ohlson et al. 2005, Ogden and Innes 2009, Gregory et al. 2012).

Climate change mitigation and adaptation are of particular concern for indigenous cultures of the Arctic, which depend upon subsistence foods as an integral part of their culture, diet, and 
Fig. 1. Steps in the structured decision analysis cycle, which we used to address climate change adaptation (Ohlson et al. 2005, Ogden and Innes 2009, Gregory et al. 2012). Steps 1 through 4 were addressed during our workshops; the remaining two steps were left to decision makers in the community.

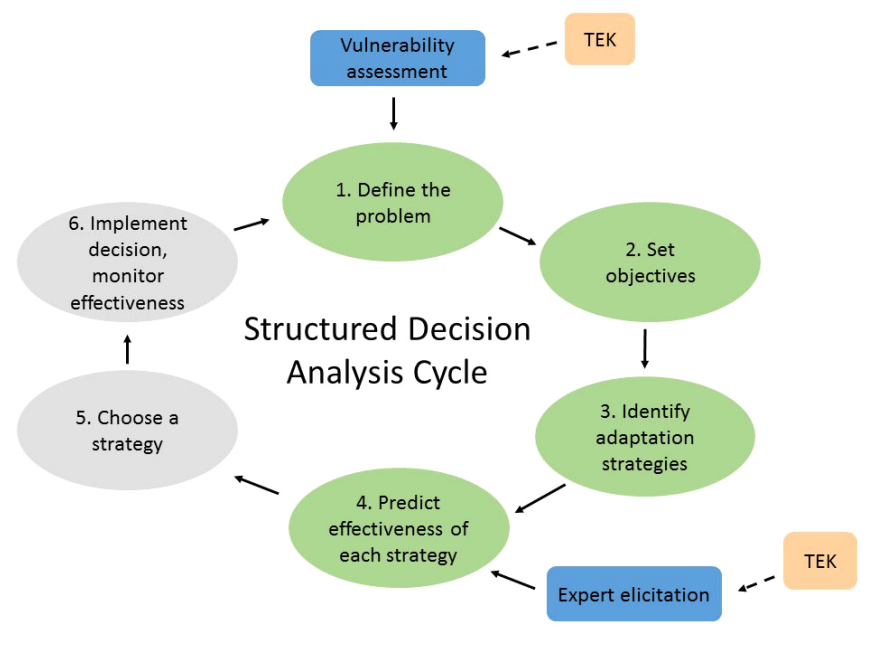

emotional and physical well-being (Condon et al. 1995, Reynolds et al. 2006, Johnson et al. 2009, Wexler et al. 2014; Watt-Cloutier 2005 petition: http://www.inuitcircumpolar.com/inuit-petitioninter-american-commission-on-human-rights-to-oppose-climatechange-caused-by-the-united-states-of-america.html). The Arctic climate has warmed at over twice the global average over the past three decades (IPCC 2013, Comiso and Hall 2014), resulting in longer ice-free seasons, shoreline erosion, shrub expansion, rain on snow events, and declining lichen abundance (Sturm et al. 2001, Stroeve et al. 2007, Lantuit and Pollard 2008, Joly et al. 2009, Rennert et al. 2009). These changes to the environment have altered the distribution and migratory patterns of many subsistence species and have resulted in more hazardous conditions for hunters (Ford et al. 2006, Jay et al. 2012, Brinkman et al. 2016, Huntington et al. 2016, Loe et al. 2016). For example, unpredictable spring ice conditions in northern Alaska have been linked to accidents and strandings of marine mammal hunters (George et al. 2004a). Despite these challenges, Arctic indigenous societies use a suite of modern and traditional adaptive strategies to help them respond to environmental change, including traditional ecological knowledge (TEK), or "the system of experiential knowledge gained by continual observation and transmitted among members of a community" (Huntington 1998:237). TEK helps people safely and successfully carry out subsistence activities, and provides the knowledge to avoid and respond to dangerous conditions (Ford et al. 2006). Additional adaptive strategies include flexible hunting schedules, the use of safety equipment, and sharing networks within and among communities (Ford et al. 2007, Ford and Goldhar 2012, Kofinas et al. 2016). Thus TEK includes knowledge about the environment and ecosystem as well as knowledge about human activities and interactions with the environment.

In this study, we worked with the Alaska Native community of Wainwright, located on the northern coast of Alaska, to understand and anticipate challenges to the subsistence system using TEK, and to build adaptive capacity using the SDA framework to enhance local decision-making processes including the documentation and analysis of relevant information. Our goals were to introduce SDA as a tool to facilitate climate change adaptation, and to have workshop participants assess the vulnerability of the subsistence system to climate change and other factors, e.g., disturbance resulting from human activity, using TEK. TEK can inform the SDA process by helping to define the problem (step 1), and by providing expert knowledge to assess how different alternatives meet objectives. We intended for this project in Wainwright to be a test case, providing a template for other communities adapting to climate change in the Arctic. Working with the community, we followed steps 1 through 5 outlined above for the application of SDA to climate change adaptation, and considered steps 6 and 7 (implementing strategies) the business of the Wainwright leadership rather than the research team. Our goal was to provide the groundwork for the decision in the form of a well-documented framework for understanding and addressing climate change vulnerabilities.

\section{STUDY AREA}

Wainwright is a village of 584 residents, of whom approximately $90 \%$ are Alaska Native (U.S. Census Bureau 2017), on the Chukchi Sea coast of northern Alaska (Fig. 2). The Arctic climate of Wainwright ranges from an average daily low of $-34^{\circ} \mathrm{C}$ in winter to an average daily high of $9^{\circ} \mathrm{C}$ in summer (WRCC 2016). Over the past 60 years, the air temperature in Arctic Alaska has increased by $3.0^{\circ} \mathrm{C}$, and this temperature shift has been most pronounced in the winter months (Stewart et al. 2013). These climatic changes have been accompanied by thawing permafrost, longer ice-free seasons, coastal storms, and flooding (Stewart et al. 2013). The lengthening of the ice-free season in the Arctic has led to increased shipping, tourism, and oil and gas extraction in the marine environment, with the potential to significantly influence both the economic and subsistence systems of northern villages (Chapin et al. 2014). Wainwright is disconnected from the road network in Alaska and is accessible by boat and plane only. The primary employers in Wainwright are the North Slope Borough (a county-like municipal government), the Olgoonik Corporation, and the City of Wainwright. The median household income in 2017 was US\$71,250, with $13.5 \%$ of families living below the poverty line (U.S. Census Bureau 2017). Dependence on subsistence foods in Wainwright ranges from $10-90 \%$ of the diet depending on the household (Wainwright Trilateral Committee 2014, Kofinas et al. 2016). Nonsubsistence food requirements are typically met by two small grocery stores and a restaurant in town. Approximately $44 \%$ of households in Wainwright self-reported as having low or very low food security in a U.S. Department of Agriculture food security survey (Kofinas et al. 2016). The primary subsistence foods in Wainwright are caribou (Rangifer tarandus, $42 \%$ of subsistence production per capita), bowhead whales (Balaena mysticetus, 31\%), 21 species of fish $(8.2 \%$ ), bearded seals (Erignathus barbatus, $7.7 \%$ ), walruses (Odobenus rosmarus, 3.7\%), belugas (Delphinapterus leucas, $3.1 \%$ ), and geese (Anser albifrons, Branta bernicla, Chen caerulescens, $1.9 \%$; Kofinas et al. 2016). Wainwright hunters travel by boat, all-terrain vehicle (ATV), and snow machine to access subsistence foods as far as $88 \mathrm{~km}$ offshore and $137 \mathrm{~km}$ inland (Fig. 2; Braund 2012, Wainwright Trilateral Committee 2014). 
Table 1. Workshop timeline.

\begin{tabular}{cll}
\hline \hline Workshop & Date & Activities \\
\hline 1 & January 2015 & $\begin{array}{l}\text { Facilitators introduce concept of structured decision making (SDA), participants define the problem (SDA step } \\
\text { 1, Appendix 1; 12 local participants) }\end{array}$ \\
2 & August 2015 & $\begin{array}{l}\text { Participants set objectives and specific topics to be addressed (SDA step 2, questions in Appendix 1; 5 local } \\
\text { participants) }\end{array}$ \\
& November 2015 & $\begin{array}{l}\text { Follow-up meeting to further define the problems and scope of topics to be addressed (Appendix 1, SDA step 2; } \\
\text { 2 local participants) }\end{array}$ \\
3 & March 2016 & $\begin{array}{l}\text { Participants identify and predict effectiveness of adaptation strategies (SDA steps 3 \& 4, Appendix 1), and assess } \\
\text { factors influencing hunter success and animal populations (SDA step 1, 7 local participants). }\end{array}$ \\
4 & August 2016 & $\begin{array}{l}\text { Participants assess vulnerability of subsistence activities to changing sea ice (SDA step 1, Appendix 1), } \\
\text { facilitators discuss results and concrete outcomes and obtain feedback from participants (3 local participants in } \\
\text { the workshop plus separate discussions with 5 local individuals, for a total of 8 local participants) } \\
\text { Facilitators present final results, participants review draft report (14 local participants) }\end{array}$ \\
\hline
\end{tabular}

Fig. 2. Map of Wainwright, Alaska displaying marine mammal and caribou subsistence use areas (Braund 2012, Wainwright Trilateral Committee 2014). N.B. The use area shown near the neighboring village of Point Lay is the area used by Wainwright hunters, not Point Lay's own use area).

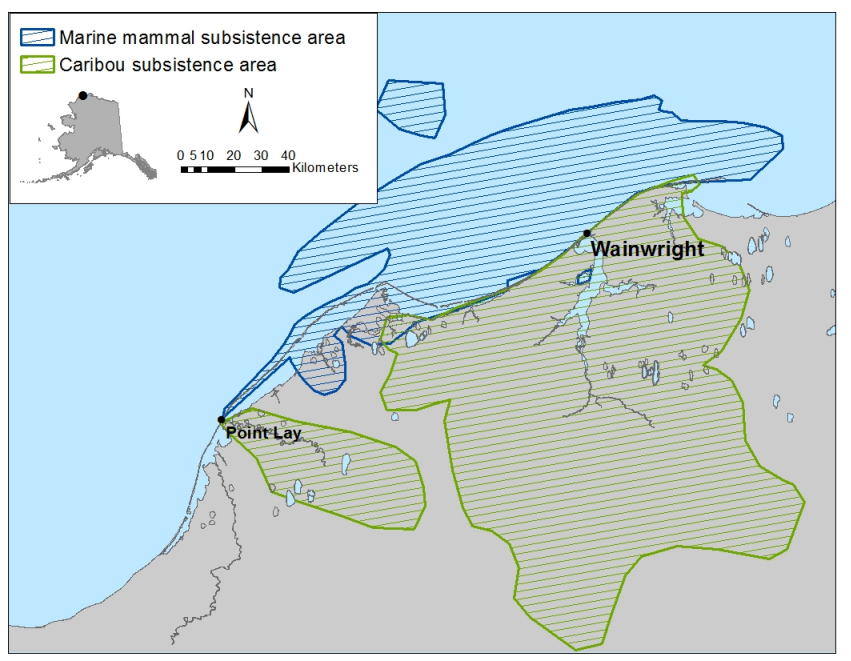

The retreat of sea ice is one of the most rapid and detectable changes in the Arctic today (Stroeve et al. 2007, Douglas 2010), and will directly impact many subsistence activities in Wainwright. Shorefast ice failures have caused strandings of hunters in northern Alaska; between 1980 and 2005, three largescale calving events near Barrow caused people to be carried out to sea on the ice (George et al. 2004b). One of these events (in 1997) caused 142 people (12 whaling camps) to be stranded at sea. Fortunately, helicopters were able to mount a successful rescue. In a recent study of rural Alaskan communities, $78 \%$ of survey respondents from northern Alaska had experienced unseasonable weather events in their community. In the same study, accidental injuries and death were linked to unusual weather patterns such as winter rain storms or sea ice failure (Driscoll et al. 2016). In Wainwright, coastal hunting grounds are accessed via a boat ramp in the lagoon alongside the village, and deploying vessels into the open ocean can be extremely dangerous when seas are rough (Wainwright Trilateral Committee 2014). Therefore, strategies to prevent accidents and enhance safe rescue are critically important. The community of Wainwright was chosen as a test case for this study because of its coastal Arctic location, strong dependence on a healthy subsistence system, the vulnerability of this system to climate change, and the anticipated increase in industrial activity in the marine environment. Furthermore, Wainwright's Trilateral Committee, consisting of representatives from Olgoonik Corporation, the Traditional Council (tribal government), and the City of Wainwright, provided a central point of contact that facilitated our ability to obtain permission to do research, organize workshops, and disseminate information about the project.

\section{METHODS}

\section{Workshop participants}

In the fall of 2014, we approached the Wainwright Trilateral Committee to describe our research and gauge their willingness to participate in the SDA process. The committee was keen to participate in the project, and our next task was to select workshop participants. To achieve an appropriate balance between the breadth of perspectives from different participants and the depth of individual engagement, SDA groups typically consist of 5-25 participants (Gregory et al. 2012). We therefore requested that the Wainwright Trilateral Committee select about 10 participants who would represent the citizens of Wainwright and involve the Olgoonik Corporation, the Traditional Council, and the City of Wainwright in the SDA process over the next two years. In addition, two students from the local high school participated in our first workshop. We therefore had participants ranging from high school age (17) to elders (up to 80 years of age). Participants included community leaders from the City of Wainwright, the Olgoonik Corporation, and the Wainwright Traditional Council. We were not able to ensure equal representation across age and sex groups, and all but two participants were men. All participants were of Iñupiat ancestry and most ( 9 of 12) were practicing or retired hunters. Collectively, we estimate that participants had over 200 years of experience in subsistence activities. We held a total of five workshops in Wainwright over two years, and each workshop typically consisted of two to four three-hour sessions over the course of two days (Table 1). 


\section{Workshop 1}

The objective of the first workshop in January 2015 was to introduce the concept of SDA, define the problem that would be addressed using the SDA approach, and discuss fundamental objectives to be addressed with SDA process (step 1, Fig. 1). Twelve Inupiat participants, representing all age groups and both genders were present at this workshop. Participants decided to take a broad approach of considering the future of Wainwright in light of the rapid pace of economic and environmental change in the Arctic, and raised concerns about how the availability and accessibility of subsistence resources have changed. The fundamental objectives (reason to be in Wainwright) and means objectives (ability to be in Wainwright) were discussed, and our SDA process was then focused on developing and addressing means objectives (relating to the ability to stay in Wainwright). In the course of open-ended discussions led by the researchers, participants shared relevant TEK pertaining to the changing environment, and this played an important role in defining the problem and was documented accordingly (step 1, SDA cycle; Fig. 1).

\section{Workshop 2}

The goal of the second workshop in August 2015 was to further define objectives and decide upon topics to focus on for the next phase of the project (steps 1 and 2; Fig. 1). Of 12 initial participants in Workshop 1, only 5 were present at Workshop 2 because the workshop coincided with a successful beluga whale hunt. At this workshop, we had one female participant and the rest were male active or retired Inupiat hunters $>40$ years of age. The SDA process was reviewed at the beginning of this meeting (using an example decision), and discussion was stimulated via an open ended question prompting participants to narrow the focus of the exercise to three specific focal issues (Appendix 1). Two members of the workshop offered to participate in a follow up working session to further refine the problem statements and specific objectives.

\section{Follow-up session in Wainwright}

We held a follow-up discussion in November 2015 with two highly engaged participants to further define the problems and scope of topics to be addressed and prepare for our third workshop, held in March 2016. One priority objective identified by participants during this meeting was establishing strategies to enhance hunter safety, a topic that was considered critical for maintaining opportunities for subsistence harvest in a rapidly changing environment. Participants were asked to identify possible strategies that could be effective in enhancing safety in the community, drawing on their TEK concerning human activities in regard to the environment, thereby developing the consequence table used in workshop 3. Another objective was to clarify our understanding of factors that influenced hunter success for four different subsistence resources (caribou, bowhead whale, walrus, bearded seal; Appendix 1). Factors that could potentially affect hunter success and abundance were identified by the authors prior to this meeting and reviewed by participants during the meeting (Appendix 1).

\section{Workshop 3}

During our third workshop (7 participants in attendance), we conducted two assessments, each of which would draw on and document TEK held by workshop participants: an analysis of hunter safety strategies; and an assessment of factors influencing key subsistence resources. At this workshop and all subsequent workshops, all participants were male active or retired hunters over the age of 40 .

We used SDA informed by TEK to evaluate the effectiveness of different strategies to enhance the safety of subsistence activities (steps 3 and 4; Fig. 1). First, participants identified three specific safety objectives: (1) prevent accidents, (2) increase the chance of rescue, and (3) minimize cost of the safety measure (Appendix 1). Each objective was assigned a weight by the participants, based on its relative importance. Second, participants listed potential strategies, and evaluated each strategy in terms of its ability to meet the objectives using a consequence table (Gregory et al. 2012). It was at this point in the SDA process that participants used their TEK concerning local hunting conditions and the challenges facing hunters to assess the relative effectiveness of each strategy. Safety strategies were ranked as having "no," "low," "moderate," "high," or a "very high" chance of meeting each objective, representing categorical performance measures to rank alternatives. Rankings were later converted to scores between 1 and 5, and scores were scaled using the following formula: (score - lowest score)/(highest score - lowest score; Gregory et al. 2012). Scores were multiplied by the predefined weightings assigned by the participants, and a total score was calculated based on the sum of the three scores for each safety strategy alternative. We then presented the table to the group and elicited feedback on whether the results made sense given how objectives were weighted.

In addition to evaluating hunter safety strategies, we elicited TEK about the environment and human activities to document the complex factors influencing local availability of wildlife and hunter success. This fed into step 1 of the SDA process, further defining the problem (Fig. 1). This exercise was based on discussions at workshop 2 and the follow-up meeting in November 2015 at which time diagrams identifying these factors were reviewed and refined by participants (Appendix 1). We conducted this assessment for four key subsistence species (bowhead whale, walrus, bearded seal, and caribou) and asked workshop participants to assess the importance of factors influencing wildlife population health and abundance, e.g., prey availability or shipping traffic, and hunter success, e.g., timing of sea ice breakup or fuel cost (Appendix 1). Surveys were filled out by individual participants and factors were given categorical rankings of "very important," "somewhat important," "not important," or "unknown." Once the surveys were collected, we tallied the number of "importance" scores in each category and then converted the score to a proportion, based on the number of participants who considered each factor very important versus somewhat or not important. For example, if 7 of 10 participants ranked the price of fuel as being "very important" in influencing hunting success for caribou, this score was converted to 0.70 . These preliminary results were the basis for a more extensive discussion among participants and researchers about wildlife abundance and accessibility.

\section{Workshop 4}

For our fourth workshop, held in August 2016, we had low turnout because of work and child care obligations ( 3 people in attendance), so we followed up with 5 additional participants 
Table 2. Structured decision analysis consequence table evaluating how different safety alternatives meet predefined objectives (workshop 3). Each objective was assigned a weight by the participants, based on its relative importance. Participants identified potential strategies, and evaluated each strategy in terms of its ability to meet the objectives. Safety strategies were ranked as having "no," "low," "moderate," "high," or a "very high" chance of meeting each objective. Categorical responses were scaled to numerical values between 0 (no effect on objective) to 1 (very high probability of meeting objective). For the cost objective, a score of $0=$ very expensive and $1=$ inexpensive. Scaling was done with the formula: (score - worst score)/(best score - worst score) for each row (Gregory et al. 2012). Scores were multiplied by the predefined weightings assigned by the participants (see above), and a total score was calculated based on the sum of the three scores for each safety strategy alternative. This consequence table was evaluated by seven participants.

\begin{tabular}{lccccccccc}
\hline \hline Objective & Weight (\%) & $\begin{array}{c}\text { Safety } \\
\text { equipment } \\
\text { sharing }\end{array}$ & $\begin{array}{c}\text { inReach group } \\
\text { discount } \\
\text { program }\end{array}$ & $\begin{array}{c}\text { SPOT group } \\
\text { discount } \\
\text { program }\end{array}$ & $\begin{array}{c}\text { Financial aid } \\
\text { for capital } \\
\text { equipment }\end{array}$ & $\begin{array}{c}\text { Safety } \\
\text { work-shops }\end{array}$ & $\begin{array}{c}\text { Hunter } \\
\text { meeting } \\
\text { place }\end{array}$ & $\begin{array}{c}\text { Docking } \\
\text { facility }\end{array}$ & $\begin{array}{c}\text { Search and } \\
\text { rescue boats }\end{array}$ \\
\hline $\begin{array}{l}\text { Prevent } \\
\text { Accidents }\end{array}$ & 40 & 0.25 & 0.00 & 0.00 & 0.75 & 1.00 & 1.00 & 1.00 & 0.00 \\
$\begin{array}{l}\text { Successful } \\
\text { rescue }\end{array}$ & 40 & 0.00 & 0.33 & 0.33 & 0.33 & 0.00 & 0.00 & 1.00 & 1.00 \\
$\begin{array}{l}\text { Minimize } \\
\text { cost }\end{array}$ & 20 & 0.50 & 0.25 & 0.50 & 0.00 & 1.00 & 0.25 & 0.00 & 0.25 \\
$\begin{array}{l}\text { Weighted } \\
\text { score }\end{array}$ & 0.20 & 0.18 & 0.23 & 0.43 & 0.60 & 0.45 & 0.80 \\
\hline
\end{tabular}

during individual meetings. In previous workshops, participants raised concerns about declines in accessibility and availability of subsistence resources due to climate change, with a focus on icedependent activities. To address these concerns, we conducted a vulnerability assessment, asking participants ( 8 total) to answer the following questions for each resource: (1) How dependent is the subsistence activity on safe ice conditions? and (2) How dependent is the species on sea ice for some or all of its life cycle? Last, for all terrestrial and marine subsistence resources, we asked the question "Have you observed a change in availability of this resource over the past decade?" (Appendix 1). The term "availability" incorporated changes in distribution (accessibility) and/or abundance of animals near Wainwright. For the first two questions, participants indicated either high, moderate, low, or unknown dependence on ice, and we converted answers to scores of 1, 2, 3, and $U$ (unknown), respectively. For the last question, participants indicated a strong decline, slight decline, no change, slight increase, or a strong increase in availability, which we later converted to scores of 1, 2, 3, 4, and 5, respectively. Each of these questions was designed to elicit and document TEK held by workshop participants. This vulnerability assessment fed into step 1 of the SDA cycle (Fig. 1), providing further clarity about the challenges facing subsistence users in Wainwright. During this workshop, we also asked participants for feedback on (a) whether the SDA process was helpful, (b) whether it could complement existing ways of decision making, and (c) what were the best ways to present the results to the people of Wainwright (Appendix 1).

\section{Workshop 5}

A final trip to Wainwright was made in January 2017 to present our study findings to the community and review a draft final report. We presented our findings to 14 people including most workshop participants and members of the Wainwright Trilateral Committee. The final report was revised based on comments received, sent to the organizations and individuals involved, and made available via digital and paper copy to the community in summer 2017.

\section{RESULTS}

\section{Workshops 1 \& 2}

Fundamental objectives and topics of concern

Participants (12 in attendance in workshop 1, 5 in attendance in workshop 2) raised concerns about how melting sea ice and stronger storms influenced the safety of hunting activities, particularly for marine mammals such as bowhead whales, bearded seals, and walruses, which require solid ice as a platform for hunters to travel on and process the animals. One participant observed "There are now stronger storms that last longer, making it more difficult to hunt whales." Participants noted that the timing of migration has changed for walruses, making it harder to anticipate their arrival in the spring. They were also worried about how increased vessel traffic and oil and gas infrastructure in the nearshore waters of the Chukchi Sea would influence wildlife populations and subsistence activities. Finally, concerns were raised about observed declines in the Western Arctic and Teshekpuk caribou herds, which provide an important year-round food for the community. One hunter commented: "Last year the caribou were scattered in smaller numbers. That makes the caribou much harder to find." The group agreed that in light of these issues, their fundamental goal was to perpetuate the subsistence way of life in the community of Wainwright into the future. During the follow-up meeting that occurred in November 2016, two participants helped refine our understanding of what factors limit hunter success for four key subsistence resources (caribou, bowhead whale, walrus, bearded seal). They also helped with the development of a consequence table (Gregory et al. 2012) including strategies for enhancing hunter safety in Wainwright (Table 2).

\section{Workshop 3}

Hunter safety assessment

A total of seven people participated in workshop 3. Our goal was to use the SDA framework to break down the fundamental objective of maintaining a subsistence lifestyle into smaller 
components to be addressed individually. One component was the issue of hunter safety, which was frequently brought up by participants. For example, one participant commented: "Crossing open water is more dangerous than it used to be because the weather is less predictable." We addressed this issue using a consequence table. Participants weighted the relative importance of each objective related to hunter safety, such that the prevention of accidents (objective 1) and maximizing the chance of rescue (objective 2) each had a weight of 0.40. Minimizing cost (objective 3 ) was given a weight of 0.20 (Table 2). We subsequently asked participants to identify different programs (alternatives) that might help them meet these objectives, and these programs included (1) a safety equipment sharing program (including Global Positioning Systems [GPS], Personal Locator Beacons [PLB], and immersion suits); (2) a program providing inReach and SPOT tracking devices to hunters; (3) a financial aid program for the purchase of equipment such as larger, more seaworthy hunting boats; (4) safety workshops; (5) a hunter meeting place for equipment repair and information transfer; (6) a new docking facility at the mouth of the local river that would facilitate safe access to hunting grounds; and (7) more seaworthy search and rescue boats (Table 2). The strategy that received the highest score $(0.80)$ was the new docking facility at the mouth of the inlet, which would help to prevent accidents, as well as increase the chance of rescue. This dock would provide easier access to marine hunting grounds than launching from the current boat ramp, which is inside a tidally influenced lagoon, providing a faster rescue response during bad weather. Although this option was one of the most expensive, it received the highest score because the cost objective was given a lower weight than rescue and prevention (Table 2). Safety workshops were ranked second (0.60), followed by the hunter meeting place $(0.45)$ and more seaworthy search and rescue boats $(0.45)$.

\section{Factors influencing wildlife abundance and hunter success}

In addition to influencing hunter safety, climate change has altered the local availability and migration timing of subsistence species. Documentation of the factors influencing hunter success and abundance of key wildlife populations could help the community anticipate how future climate change and development might influence the subsistence system. For this exercise, we focused on caribou, bowhead whales, bearded seals, and walruses because of their importance as subsistence resources in Wainwright. Seven participants completed this survey during workshop 3, and an additional participant completed the survey in workshop 4. The perceived importance of each factor for each species can be found in Appendix 2. Herein, we focus on factors that were considered "very important" by participants (Figs. 3, 4). For caribou, $83 \%$ of participants thought the price of fuel was very important in influencing hunter success (Fig. 3A). Of the respondents, $78 \%$ agreed that population health and abundance was a function of synchrony of calf birth (which is thought to decrease predation), summer forage quality, snow depth and compaction, and surface icing from freezing rain events (Fig. 3A). For bowhead whales, $100 \%$ of respondents thought that shorefast ice thickness and timing of migration were very important factors influencing hunter success. Of the respondents, $88 \%$ felt that timing of sea ice breakup, access to hunting equipment, and hunter expertise were very important factors influencing hunter success (Fig. 3B). Of the participants, 78\% thought that bowhead whale health and abundance depended largely on zooplankton prey abundance (Fig. 3B). For walruses, hunter success was considered to be primarily a function of distance from shore of migrating walruses $(100 \%$ of respondents), the amount of broken ice near shore $(100 \%)$, abundance of walruses $(89 \%)$, and access to equipment ( $88 \%$; Fig. 4A). For walrus health and abundance, $88 \%$ of participants thought the extent of sea ice retreat was a very important factor. For bearded seal hunting success, $100 \%$ of respondents thought access to equipment was very important, $89 \%$ thought amount of broken ice near shore was very important, and $78 \%$ considered the abundance of seals, timing of spring migration, and timing of sea ice breakup to be very important (Fig. 4B). Overall, there was little agreement about the most important factors influencing bearded seal health and abundance. Factors that were considered unknown by many participants included the effects of predation by killer whales (Orcinus orca) and shipping traffic on marine mammals.

\section{Workshop 4}

Vulnerability assessment

Workshop participants (8) assessed 15 species or species groups in terms of their vulnerability to sea ice loss and the dependence of hunting activities on sea ice. Furthermore, changes in availability over the past decade were assessed for each species. Walruses, bearded seals, and smelt (Osmerus mordax) received high scores for dependence on sea ice by both the animal and the hunter (Fig. 5). Bowhead whale (spring hunt only) hunting activities were also considered to depend strongly on ice, but the animals themselves were only moderately dependent on the ice (Fig. 5). Sea ducks received moderate scores for dependence on ice by the animal and hunter. Tomcod (Microgadus tomcod), whitefish (Coregonus nasus), and salmon (Oncorhynchus spp.) were perceived to have increased slightly over the past decade near Wainwright (Fig. 6). The only species assessed as declining significantly was caribou. For all other species, 95\% confidence intervals overlapped 3 (the score for no change), indicating no perceived change in availability (Fig. 6).

\section{Participant feedback and products of SDA process}

We asked participants whether the SDA process was helpful and could complement the existing decision-making process in Wainwright, and what products of the study would benefit the community. Participants mentioned that our workshops helped them conceptualize and make explicit in their own minds the various factors influencing key subsistence species and their successful harvest. They also commented that SDA "brought out some issues that would not have been thought of." Workshop participants suggested that we summarize both the process of applying SDA and the results of our workshops in a comprehensive report to the community. Participants were particularly interested in archiving TEK in written format, and with regards to changes in subsistence species and their habitat, noted that "it is good to see things on paper." In response to this request, our final report to the community reported the TEK results in some detail, and they are also discussed below in depth to help create a lasting record.

\section{DISCUSSION}

Wainwright's location on the Arctic coast and heavy reliance on subsistence resources have prompted concern about the long-term 
Fig. 3. Factors influencing hunter success (outlined in red) and health and abundance (outlined in blue) of (A) caribou (Rangifer tarandus) and (B) bowhead whales (Balaena mysticetus) identified in workshops in Wainwright, Alaska. The darkness of arrows indicates the proportion of people who considered each factor as "very important." Factors that were considered "very important" by $>80 \%$ of respondents are in bold. See Appendix 2 for a full table of results. Data were collected during workshops 3 and 4 by 8 participants.

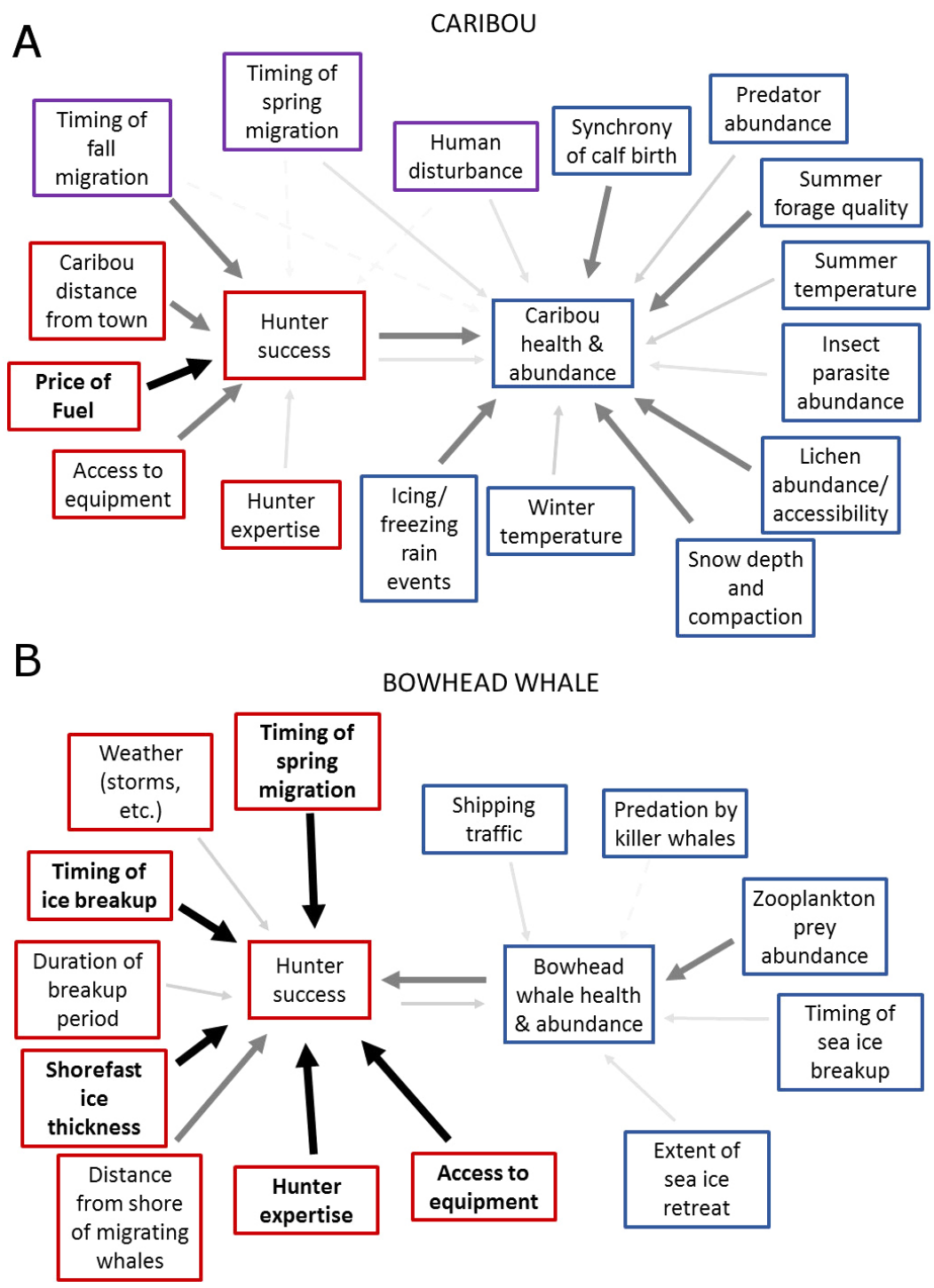

viability of subsistence activities in the face of accelerating climate change. Major challenges faced by hunters in Wainwright included increasingly unpredictable ice conditions, stronger winds and wave action, earlier seasonal migrations of marine mammals, declining caribou abundance, and thawing ice cellars. To confront these challenges, people in Wainwright have a number of adaptations in place including the use of traditional knowledge to anticipate unsafe conditions, flexible hunting strategies, and the use of social media to track animal migrations (K. Christie, T. Hollmen, H. P. Huntington, and J. Lovvorn, personal observation). Wainwright is not alone in experiencing these changes, which are affecting indigenous communities throughout the Arctic (Callaway et al. 1999, Ford et al. 2006, Cochran et al. 2013).

Hunter safety assessment

Participants' detailed knowledge of hunting practices, transportation routes, and safety risks provided the expertise required to evaluate the effectiveness of each safety strategy. This inclusion of TEK in the decision-making process led to greater clarity of what future practices and programs the community 
Fig. 4. Factors influencing hunter success (outlined in red) and health and abundance (outlined in blue) of (A) walruses (Odobenus rosmarus) and (B) bearded seals (Erignathus barbatus) identified in workshops in Wainwright, Alaska. The darkness of arrows indicates the proportion of people who considered each factor as "very important." Factors that were considered "very important" by $>80 \%$ of respondents are in bold. See Appendix 2 for a full table of results. Data were collected during workshops 3 and 4 by 8 participants.

A WALRUS

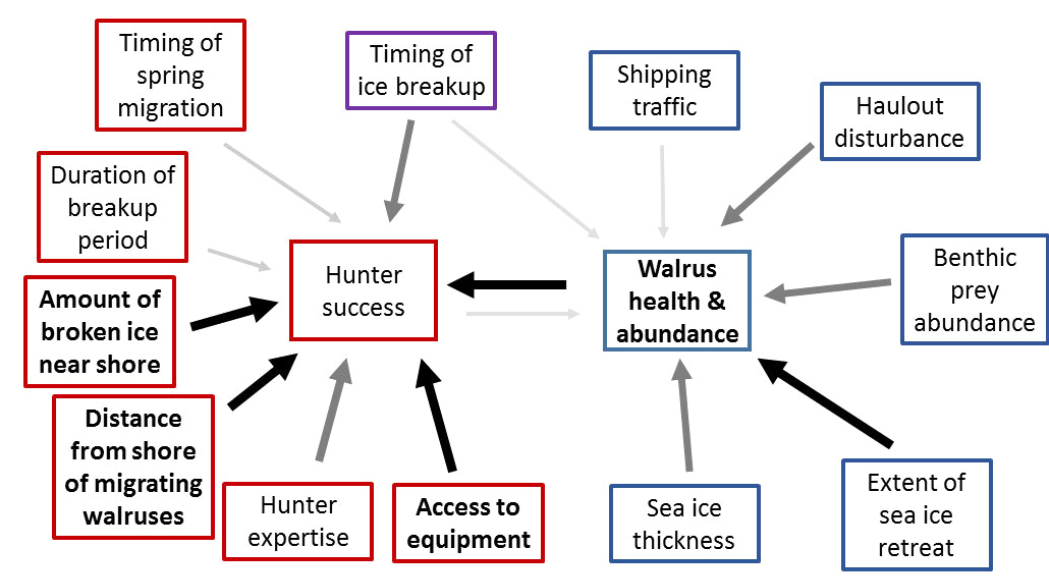

B

BEARDED SEAL

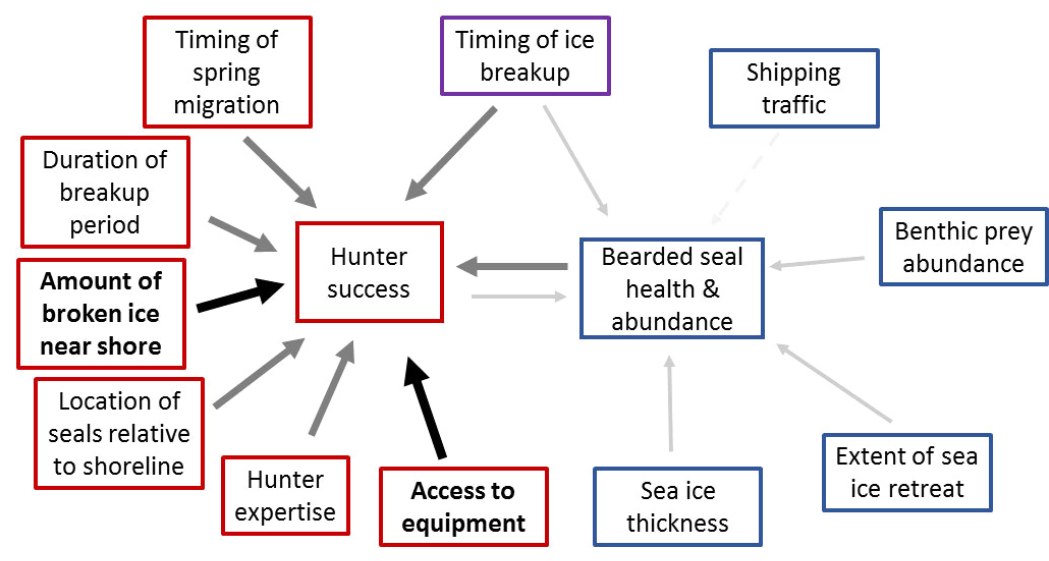

should invest in, and identified important trade-offs, e.g. cost. In addition, the exercise resulted in detailed documentation that justified the selection of top safety strategies. This enhanced clarity and justification of choices likely would not have taken place without the SDA framework. Participants viewed minimizing cost as being less important than accident prevention and successful rescue leading to the priority alternative of a new docking facility, which would make it safer to access coastal hunting grounds during bad weather, and would provide a quicker response for search and rescue operations (Wainwright Trilateral Committee 2014). This high-priority strategy would require a significant investment from outside sources that is currently not available for climate change adaptation. However, as a direct result of this exercise, the Tribe applied for and obtained funding through the Center for Disease Control to implement some of the other safety strategies. With this funding, the community decided to enhance the existing search and rescue program by creating an inReach tracking device loan program and implementing safety training workshops. Although these strategies received lower priority in our workshops compared to the docking facility, they were more practical given the amount of funding available at the time. The fact that the most effective safety strategy (a new docking facility) was too expensive given the available funding opportunities points to the need for significant financial investment for climate change adaptation, most likely at higher levels of government. 
Fig. 5. Relative dependence on sea ice of subsistence resources and activities near Wainwright, Alaska. Resources were assessed on a scale of 1 (low dependence) to 3 (high dependence). Error bars denote $95 \%$ confidence intervals. Data were collected during workshop 4 by 9 participants.

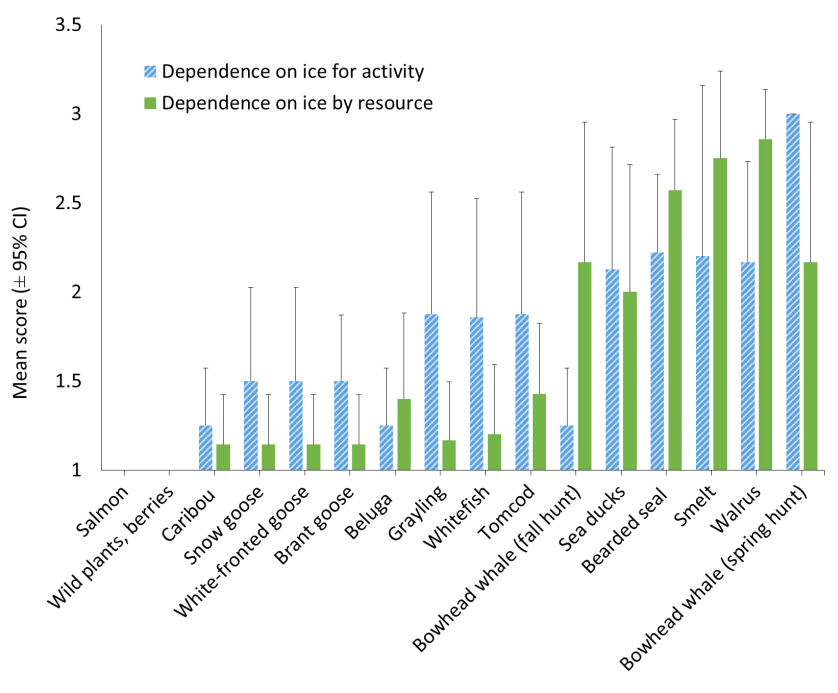

Fig. 6. Relative change in availability of subsistence resources as perceived by workshop participants in Wainwright, Alaska. Resources were assessed on a scale of 1 (strong decrease in availability) to 5 (strong increase in availability), with a score of 3 indicating no change. Bars extending above the dotted line indicate that availability has increased; bars ending below the dotted line indicate that availability has decreased. Asterisks denote species or groups where $95 \%$ confidence intervals do not overlap 3. Data were collected during workshop 4 from 9 participants.

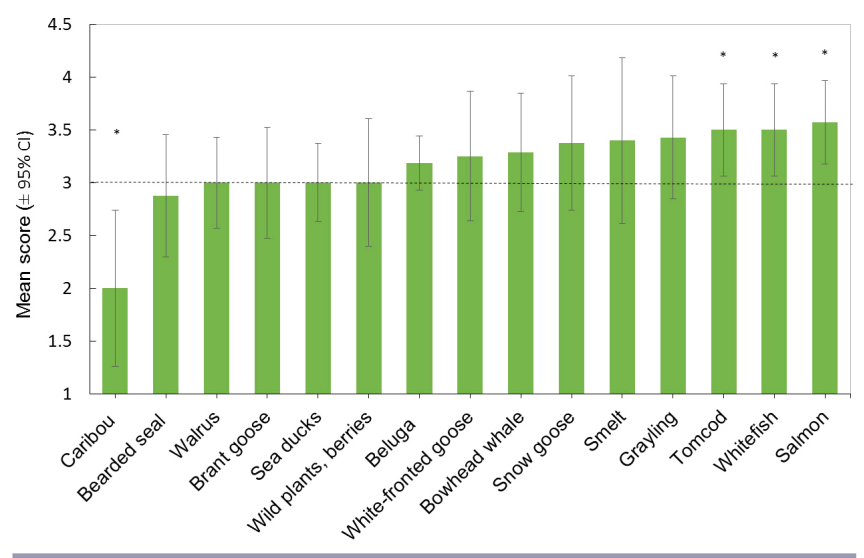

Factors influencing wildlife abundance and hunter success Our workshops provided documentation of the relative importance of factors influencing the health and abundance of key subsistence species. This information is useful for the community as written documentation of those aspects of TEK, and is pertinent to researchers interested in Arctic wildlife ecology. Furthermore, this information can be incorporated into step 1 of the SDM process (Fig. 1), helping to define the problem or challenge to be addressed. Climatic factors including rain-onsnow events and extent of sea ice retreat were considered important determinants of health and abundance of caribou and walrus, respectively, and these factors have also been reported in the scientific literature (Cooper et al. 2006, Jay et al. 2012, Loe et al. 2016, Sokolov et al. 2016). Icing events and sea ice retreat are expected to worsen under realistic climate scenarios (Rennert et al. 2009, Douglas 2010), with probable negative outcomes for caribou and walruses. Food availability, in the form of zooplankton (bowhead whale), benthic invertebrates (walrus), or summer forage (caribou) was also considered to be important in predicting abundance and population health. Climate change has variable impacts on food availability for these species. For caribou, rain-on-ice events in the winter can limit access to lichens (Sokolov et al. 2016), although summer forage biomass is expected to increase with warmer summer temperatures (Epstein et al. 2000, Kruse et al. 2004). For bowhead whales, climate change seems to have had a positive impact on health because the reduction of sea ice in the Arctic has been linked to increased body condition, mediated by increased productivity of pelagic zooplankton (George et al. 2015). For walruses, in warm summers when sea ice retreats beyond the continental shelf where waters are too deep for foraging, animals tend to haul out on land (Jay et al. 2012, Udevitz et al. 2013). This may pose challenges for walruses because (a) they may need to make longer foraging trips to access benthic foods; (b) large terrestrial haulouts are prone to stampedes causing significant calf mortality; and (c) walrus calves are more susceptible to terrestrial predators (Fay 1982, Jay et al. 2012, Udevitz et al. 2013).

It is informative to examine factors that were considered unimportant in influencing population health and abundance, as well as factors for which there was high uncertainty. Predation and harvest were not considered to be important factors in predicting health and abundance of the assessed species. Furthermore, with the exception of haulout disturbance of walruses, human disturbance and shipping traffic were considered to be only marginally important in comparison with other factors. This may be because the harvest of marine mammals and caribou is highly regulated in the U.S. (George et al. 2004b, Metcalf and Robards 2008, Harper 2013). Some key uncertainties highlighted by this survey (in the form of a response of "unknown") were the effects of shipping traffic and predation by killer whales on marine mammals (Appendix 2). Vessel traffic and other forms of disturbance are currently fairly low around Wainwright because of the small size of the village and absence of significant development in the region, although this may change. Killer whales appear to be increasing in Arctic waters coincident with reduced sea ice (Higdon and Ferguson 2009).

Our workshops documented the key factors limiting hunter success in the vicinity of Wainwright. For caribou, hunter success depends in large part on the price of fuel. The high cost of living combined with limited cash-generating opportunities makes it difficult to have cash on hand to purchase both fuel and equipment in Wainwright. High fuel costs are of concern for many Alaskan rural villages, and when cash is scarce, hunters will travel shorter distances, hunt less frequently, and delay paying household bills 
in favor of purchasing fuel (Brinkman et al. 2014). For bowhead whales, timing of spring migration and sea ice breakup were important factors influencing hunter success. When the timing of migration changes because of changing sea ice conditions, it becomes difficult to predict the arrival of animals, and at times conditions are not conducive to successful hunting. For example, workshop participants explained that when bowhead whales migrate through leads in the sea ice early in the spring, hunters may be unprepared for their arrival and/or find it difficult to hunt under extremely cold temperatures. A successful spring bowhead whale hunt requires that whales migrate close to Wainwright when there is sufficiently thick sea ice to support the weight of snow machines and the whales themselves. Hunter expertise appeared to be more important for hunting bowhead whales than any other species; this is likely due to the skill required to land a whale (Kassam and The Wainwright Traditional Council 2001). Access to equipment was an important factor limiting hunter success for all marine mammal species, and it may become increasingly challenging for marine mammal hunters to operate their small boats safely as sea ice declines and stronger winds and wave action become the norm in Arctic waters (Overeem et al. 2011, Wang and Overland 2015). The thickness and amount of ice near shore was also important for marine mammal hunters so that they could safely approach and process marine mammals. The need for ice as a platform for hunters to access marine life has been documented throughout the Arctic, and the decreasing thickness of shorefast ice is now a key safety concern (George et al. 2004b, Ford et al. 2006, Statham et al. 2015).

\section{Dependence on sea ice and changes in availability of subsistence resources}

Walruses, bearded seals, bowhead whales, smelt, and sea ducks were identified as being dependent on sea ice, as were hunting activities for these species; therefore, these components of Wainwright's subsistence system are vulnerable to sea ice loss. Sea ice suppresses storm waves, and walruses, bearded seals, and sea ducks use sea ice as a resting platform that for sea ducks reduces the high thermoregulation costs of being in water (Burns 1981, Fay 1982, Lovvorn et al. 2009). In an assessment of marine mammal sensitivity to climate change, walruses were considered to be particularly sensitive because of their dependence on sea ice, dietary specialization, limited range, and relatively low potential for population growth (Laidre et al. 2008). Bowhead whales also associate with some form of ice for much of the year because ice confers benefits in the form of high prey densities and a refuge from killer whales (Ferguson et al. 2010). Whereas the harvest of walruses, bearded seals, sea ducks, and bowhead whales (spring hunt) is highly dependent on safe ice conditions, the bowhead whale hunt during the fall and beluga whale hunt in the summer occur in open water and therefore are not as dependent on safe ice conditions.

The assessment of the changing availability of subsistence species documented insights about future food security in Wainwright. Of 15 species examined, only one (caribou) was observed to be declining in availability. Nevertheless, caribou are an extremely important food in Wainwright, with community production of caribou meat averaging $284 \mathrm{lbs}$ of caribou per year (Kofinas et al. 2016). This single species accounts for $42 \%$ of the entire subsistence production of Wainwright (Kofinas et al. 2016). The decline of the Western Arctic Caribou Herd prior to 2016 was thought to be due to a combination of predation and poor snow conditions, and numbers appear to be stabilizing (Parrett 2016). Whether or not climate change will cause further declines in caribou numbers in northern Alaska is unknown, but caribou appear to be declining elsewhere in their range (Vors and Boyce 2009). On one hand, rain-on-snow events, declining lichen abundance, and trophic mismatches have been proposed as mechanisms by which climate change can have a negative impact on caribou (Post and Forchhammer 2008, Joly et al. 2009, 2011, Rennert et al. 2009). On the other hand, climate change may improve growing conditions for forage plants on the summer grounds (Joly et al. 2011).

A source of cautious optimism for the community is that the Bering-Chukchi-Beaufort Sea bowhead whale population has been steadily increasing (Givens et al. 2015). Bowhead whales compose $31 \%$ of subsistence production (by weight) in Wainwright, and their harvest plays a pivotal role in Iñupiat culture (Kassam and The Wainwright Traditional Council 2001, Kofinas et al. 2016). Furthermore, all fish species assessed by our workshop participants were observed to be increasing slightly in availability, and this is echoed by reports in the scientific literature of increased salmon densities in the Chukchi Sea (Logerwell et al. 2015). Fish currently compose $8 \%$ of subsistence production in Wainwright (Kofinas et al. 2016). Snow geese have also increased in the Arctic over the past decade (Hupp et al. 2015), although they constitute a relatively small portion of subsistence production $(<1 \%$; Kofinas et al. 2016).

Because of its coastal location and proximity to the mouth of a river, Wainwright is fortunate in having a highly diverse subsistence system that may in part buffer the negative effects of climate change. Furthermore, most species harvested in Wainwright are stable or increasing. However, when one considers issues of changing availability and access of key foods that dominate the diet, there is cause for concern. Caribou, bowhead whale, bearded seal, walrus, and beluga make up $88 \%$ of total subsistence production in Wainwright (Kofinas et al. 2016). Local caribou populations are known to experience dramatic fluctuations in abundance (Parrett 2016). Moreover, bowheads, bearded seals, and walruses require thick shorefast ice for successful harvest (although for bowhead whales, this applies to the spring hunt only), and occurrence of such ice has declined. Therefore, because of either reduced access or availability, four out of five of these key subsistence foods have the potential to be compromised, depending on the status of the population (caribou) and ice conditions (bowhead whale, walrus, bearded seal). A transition to a fall hunt would alleviate the problem of access to bowhead whales, although hunters may require larger boats and/or motors to withstand rough seas and travel farther from shore (Metcalf and Robards 2008, Hansen et al. 2013, Vermaire et al. 2013).

\section{Strengths and limitations}

The format of this study as a series of workshops had strengths and limitations. A series of consecutive workshops with the same participants allowed relationships to be established and built familiarity, and promoted engagement by participants in all steps of the SDA process. It also led to a clear, comprehensive definition of problems and possible solutions over time. This approach allowed us to document current and future challenges and 
adaptive strategies used by the community of Wainwright. A weakness of this format was that it was difficult to replace a participant unable to attend a workshop. Therefore, attendance was at times low, and we were required to follow up with individual participants to ensure maximum participation. An additional weakness was that the selection of participants by the Trilateral Committee of Wainwright resulted in unequal representation of the sexes: only 2 of our 12 participants were female. Therefore, our study was limited largely to the male point of view and may overlook issues of importance to female subsistence users, e.g., harvesting of plants and berries (Dowsley 2015). Furthermore, the appointment of participants by the Trilateral Committee may have caused us to not sample all possible viewpoints in the community. Nevertheless, it was necessary for us to follow established protocols for outside researchers and to secure the support and engagement of community leadership. Last, our approach could be improved by eliciting anonymous feedback from participants on workshop process while researchers were not present. This may provide a clearer picture of the limitations of the study from the perspective of the participants.

\section{Traditional ecological knowledge and decision analysis}

This study presents a novel approach that incorporates TEK into the decision analysis framework in an Arctic subsistence community. A frequently used tool by SDA practitioners is the "expert elicitation," which helps predict how different alternatives meet the stated objectives (Runge et al. 2011, Gregory et al. 2012). In this study, we considered the workshop participants, who collectively had over 200 years of experience with subsistence activities, to be the experts. We elicited their expert knowledge through a series of open-ended questions posed to the group to describe the scope of the problem, as well as more focused surveys to assess the vulnerability of the subsistence system and evaluate the relative effectiveness of different climate adaptation strategies. Incorporating TEK as a form of expert elicitation serves the additional purpose of archiving TEK for future generations. In the context of this paper, we found TEK to be particularly useful in elucidating the factors limiting the successful harvest of wildlife and selecting strategies that would enhance the safety of hunting activities. Therefore, we consider the documentation of TEK to be critical to assessing vulnerability to climate change, and identifying adaptation strategies in indigenous communities. We recommend that practitioners receive training in SDA and community engagement prior to facilitating workshops.

\section{SDA as a framework for adaptation to climate change}

We suggest that SDA provides an effective way to facilitate climate change adaptation, by directly engaging community members to identify specific problems, formulate objectives, and rank alternative adaptive strategies. Our hunter safety consequence table showed how different adaptive strategies can be prioritized by local stakeholders based on conditions unique to their community. Our documentation of how top-ranked strategies were selected can be used by the community to justify funding requests and secure grants from outside sources. The SDA approach has been widely recommended for difficult decisions regarding natural resources (Conroy et al. 2011, Holland-Bartels and Pierce 2011, Martin et al. 2011, Nichols et al. 2011), and we believe it has significant potential to aid in adaptation planning for climate change. Furthermore, SDA provides a framework by which federal, state, and territorial agencies can work with northern indigenous communities to develop climate change policies and programs that meet their needs. We recommend participatory approaches such as this one that engage communities at the local level, building on existing decisionmaking processes in the community, to identify challenges to their way of life and prioritize adaptive strategies for dealing with these challenges. This type of approach has a higher likelihood of being embraced than top-down policies because it considers the challenges, objectives, and cultural practices unique to each community, and empowers individuals to proactively strategize about adapting to climate change (Newton et al. 2005, Chapin et al. 2006).

Responses to this article can be read online at: http://www.ecologyandsociety.org/issues/responses. php/10596

\section{Acknowledgments:}

We thank workshop participants in Wainwright for contributing their time and effort to this project, and for sharing their knowledge with us. We thank the Trilateral Committee of Wainwright, including the Olgoonik Corporation, the City of Wainwright, and the Traditional Council for their support of this project. We thank Lynn Nappi for her help with travel and research logistics. This project is funded by the NSF ArcSEES program (grant \# 1262825), and has been reviewed and approved by the Southern Illinois University Human Subjects Committee (IRB \# 15233). We also thank two anonymous reviewers, whose constructive suggestions improved the paper immensely.

\section{LITERATURE CITED}

Adger, W. N., S. Dessai, M. Goulden, M. Hulme, I. Lorenzoni, D. R. Nelson, L. O., Naess, J. Wolf, and A. Wreford. 2009. Are there social limits to adaptation to climate change? Climatic Change 93:335-354. http://dx.doi.org/10.1007/s10584-008-9520$\underline{z}$

Braund, S. 2012. Summary of marine subsistence uses: Barrow and Wainwright, Alaska. Pew Environment Group. Seattle, Washington, USA.

Brinkman, T. J., W. D. Hansen, F. S. Chapin III, G. Kofinas, S. Burnsilver, and T. S. Rupp. 2016. Arctic communities perceive climate impacts on access as a critical challenge to availability of subsistence resources. Climatic Change 139(3-4):413-427. http:// dx.doi.org/10.1007/s10584-016-1819-6

Brinkman, T., K. B. Maracle, J. Kelly, M. Vandyke, A. Firmin, and A. Springsteen. 2014. Impact of fuel costs on high-latitude subsistence activities. Ecology and Society 19(4):18. http://dx.doi. org/10.5751/ES-06861-190418

Burns, J. 1981. Bearded seal, Erignathus barbatus Erxleben. Page 1777in S. Ridgeway and R. Harrison, editors. Handbook of marine mammals, seals. Academic Press, London, UK.

Callaway, D., J. Eamer, E. Edwardsen, C. Jack, S. Marcy, A. Olrun, M. Patkotak, D. Rexford, and A. Whiting. 1999. Effects of climate change on subsistence: a consensus position. Pages 59-74 in 
Proceedings of a workshop, Assessing the consequences of climate change for Alaska and the Bering Sea region, Fairbanks, Alaska 29-30 October 1998.

Cameron, E. S. 2012. Securing indigenous politics: a critique of the vulnerability and adaptation approach to the human dimensions of climate change in the Canadian Arctic. Global Environmental Change 22(1):103-114. http://dx.doi.org/10.1016/ j.gloenvcha.2011.11.004

Chapin III, F. I., M. Hoel, S. R. Carpenter, J. Lubchenco, B. Walker, T. V. Callaghan, C. Folke, S. A. Levin, K.-G. Mäler, C. Nilsson, et al. 2006. Building resilience and adaptation to manage Arctic change. Ambio 35:198-202. http://dx.doi.org/10.1579/0044-7447 (2006)35[198:BRAATM]2.0.CO;2

Chapin, F. I., S. Trainor, P. Cochran, H. Huntington, C. Markon, M. McCammon, A. McGuire, and M. Serreze. 2014. Alaska. Pages 514-536 in J. Melillo, T. Richmond, and G. Yohe, editors. Climate change impacts in the United States: the third national climate assessment. U.S. Global Research Program, Washington, D.C., USA.

Cochran, P., O. H. Huntington, C. Pungowiyi, S. Tom, F. S. Chapin III, H. P. Huntington, N. G. Maynard, and S. F. Trainor. 2013. Indigenous frameworks for observing and responding to climate change in Alaska. Climatic Change 120:557-567. http:// dx.doi.org/10.1007/s10584-013-0735-2

Comiso, J. C., and D. K. Hall. 2014. Climate trends in the Arctic as observed from space. WIREs Climate Change 5(3):389-409. http://dx.doi.org/10.1002/wcc.277

Condon, R. G., P. Collings, and G. Wenzel. 1995. The best part of life: subsistence hunting, ethnicity, and economic adaptation among young adult Inuit males. Arctic 48(1):31-46. http://dx.doi. org/10.14430/arctic1222

Conroy, M. J., M. C. Runge, J. D. Nichols, K. W. Stodola, and R. J. Cooper. 2011. Conservation in the face of climate change: the roles of alternative models, monitoring, and adaptation in confronting and reducing uncertainty. Biological Conservation 144(4):1204-1213. http://dx.doi.org/10.1016/j.biocon.2010.10.019

Cooper, L. W., C. Ashjian, S. Smith, L. A. Codispoti, J. Grebmeier, R. Campbell, and E. Sherr. 2006. Rapid seasonal sea-ice retreat in the Arctic could be affecting pacific walrus (Odobenus rosmarus divergens) Recruitment. Aquatic Mammals 32:98-102. http://dx. doi.org/10.1578/AM.32.1.2006.98

Douglas, D. C. 2010. Arctic sea ice decline: projected changes in timing and extent of sea ice in the Bering and Chukchi Seas. OpenFile Report 2010-1176. U.S. Geological Survey, Washington, D. C., USA. http://dx.doi.org/10.3133/ofr20101176

Dowsley, M. 2015. Identity and the evolving relationship between Inuit women and the land in the eastern Canadian Arctic. Polar Record 51(5):536-549. http://dx.doi.org/10.1017/S0032247414000564

Driscoll, D. L., E. Mitchell, R. Barker, J. M. Johnston, and S. Renes. 2016. Assessing the health effects of climate change in Alaska with community-based surveillance. Climatic Change 137:455-466. http://dx.doi.org/10.1007/s10584-016-1687-0

Easterling III, W. E., B. H. Hurd, and J. B. Smith. 2004. Coping with global climate change: the role of adaptation in the United
States. Pew Centre on Global Climate Change, Arlington, Virginia, USA.

Epstein, H. E., M. D. Walker, F. S. Chapin III, and A. M. Starfield. 2000. A transient, nutrient-based model of arctic plant community response to climatic warming. Ecological Applications 10(3):824-841. http://dx.doi.org/10.1890/1051-0761 (2000)010[0824:ATNBMO]2.0.CO;2

Fay, F. H. 1982. Ecology and biology of the Pacific walrus, Odobenus rosmarus divergens Illiger. North American Fauna 74:1-279. http://dx.doi.org/10.3996/nafa.74.0001

Ferguson, S. H., L. Dueck, L. L. Loseto, and S. P. Luque. 2010. Bowhead whale Balaena mysticetus seasonal selection of sea ice. Marine Ecology Progress Series 411:285-297. http://dx.doi. org/10.3354/meps08652

Ford, J. D., and C. Goldhar. 2012. Climate change vulnerability and adaptation in resource dependent communities: a case study from West Greenland. Climate Research 54(2):181-196. http://dx. doi.org/10.3354/cr01118

Ford, J. D., G. Mcdowell, and T. Pearce. 2015. The adaptation challenge in the Arctic. Nature 5(12):1046-1053. http://dx.doi. org/10.1038/nclimate 2723

Ford, J. D., T. Pearce, F. Duerden, C. Furgal, and B. Smit. 2010. Climate change policy responses for Canada's Inuit population: the importance of and opportunities for adaptation. Global Environmental Change 20:177-191. http://dx.doi.org/10.1016/j. gloenvcha.2009.10.008

Ford, J., T. Pearce, B. Smit, J. Wandel, M. Allurut, K. Shappa, H. Ittusujurat, and K. Qrunnut. 2007. Reducing vulnerability to climate change in the Arctic: the case of Nunavut, Canada. Arctic 60(2):150-166. http://dx.doi.org/10.14430/arctic240

Ford, J. D., B. Smit, and J. Wandel. 2006. Vulnerability to climate change in the Arctic: a case study from Arctic Bay, Canada. Global Environmental Change 16:145-160. http://dx.doi.org/10.1016/j. gloenvcha.2005.11.007

George, J. C., J. Zeh, R. Suydam, and C. Clark 2004a. Abundance and population trend (1978-2001) of Western Arctic bowhead whales surveyed near Barrow, Alaska. Marine Mammal Science 20:755-773. http://dx.doi.org/10.1111/j.1748-7692.2004.tb01191. $\underline{x}$

George, J. C., H. P. Huntington, K. Brewster, H. Eicken, D. W. Norton, and R. Glenn. 2004b. Observations on shorefast ice dynamics in Arctic Alaska and the responses of the Iñupiat hunting community. Arctic 57(4):363-374. http://dx.doi. org/10.14430/arctic514

George, J. C., M. L. Druckenmiller, K. L. Laidre, R. Suydam, and B. Person. 2015. Bowhead whale body condition and links to summer sea ice and upwelling in the Beaufort Sea. Progress in Oceanography 136:250-262. http://dx.doi.org/10.1016/j. pocean.2015.05.001

Givens, G. H., J. C. George, and R. Suydam. 2015. A population dynamics model and assessment of Bering-Chukchi-Beaufort Seas bowhead whales. International Whaling Commission, Cambridge, UK. 
Grace, K., F. Davenport, C. Funk, and A. Lerner. 2012. Child malnutrition and climate in sub-Saharan Africa: an analysis of recent trends in Kenya. Applied Geography 35(1-2):405-413. http://dx.doi.org/10.1016/j.apgeog.2012.06.017

Gregory, R., L. Failing, M. Harstone, G. Long, T. McDaniels, and D. Ohlson. 2012. Structured decision making: a practical guide to environmental management choices. John Wiley \& Sons, Chichester, UK. http://dx.doi.org/10.1002/9781444398557

Hansen, W. D., T. J. Brinkman, M. Leonawicz, F. S. Chapin III, and G. P. Kofinas. 2013. Changing daily wind speeds on Alaska's North Slope: implications for rural hunting opportunities. Arctic 66(4):448-458. http://dx.doi.org/10.14430/arctic4331

Harper, P. 2013. Caribou management report of survey-inventory activities 2010-2012. Alaska Department of Fish and Game Species Management Report, Juneau, Alaska, USA.

Higdon, J. W., and S. H. Ferguson. 2009. Loss of Arctic sea ice causing punctuated change in sightings of killer whales (Orcinus orca) over the past century. Ecological Applications 19 (5):1365-1375. http://dx.doi.org/10.1890/07-1941.1

Holland-Bartels, L., and B. Pierce. 2011. An evaluation of the science needs to inform decisions on outer continental shelf energy development in the Chukchi and Beaufort Seas, Alaska. U.S. Geological Survey, Anchorage, Alaska.

Huntington, H. P. 1998. Observations on the utility of the semidirective interview for documenting traditional ecological knowledge. Arctic 51:237-242. http://dx.doi.org/10.14430/ arctic1065

Huntington, H. P., L. T. Quakenbush, and M. Nelson. 2016. Effects of changing sea ice on marine mammals and subsistence hunters in northern Alaska from traditional knowledge interviews. Biology Letters 12:4-7. http://dx.doi.org/10.1098/ $\underline{\text { rsbl.2016.0198 }}$

Hupp, J., D. Ward, M. E. Whalen, and J. M. Pearce. 2015. Changing Arctic ecosystems - What is causing the rapid increase of snow geese in northern Alaska? Fact Sheet 2015-3062. U.S. Geological Survey, Anchorage, Alaska.

Intergovernmental Panel on Climate Change (IPCC). 2013. Summary for policy makers. In T. F. Stocker, D. Qin, G.-K. Plattner, M. Tignor, S. K. Allen, J. Boschung, A. Nauels, Y. Xia, V. Bex and P. M. Midgley, editors. Climate change 2013: the physical science basis. Contribution of Working Group I to the Fifth Assessment Report of the Intergovernmental Panel on Climate Change. Cambridge University Press, Cambridge, UK. http://dx. doi.org/10.1017/CBO9781107415324.004

Intergovernmental Panel on Climate Change (IPCC). 2014. Summary for policymakers. In C. B. Field, V. R. Barros, D. J. Dokken, K. J. Mach, M. D. Mastrandrea, T. E. Bilir, M. Chatterjee, K. L. Ebi, Y. O. Estrada, R. C. Genova, B. Girma, E. S. Kissel, A. N. Levy, S. MacCracken, P. R. Mastrandrea, and L. L. White, editors. Climate change 2014: impacts, adaptation, and vulnerability. Part A: global and sectoral aspects. Contribution of Working Group II to the Fifth Assessment Report of the Intergovernmental Panel on Climate Change. Cambridge University Press, Cambridge, UK. http://dx.doi.org/10.1017/ CBO9781107415379.003
Jay, C. V., A. S. Fischbach, and A. A. Kochnev. 2012. Walrus areas of use in the Chukchi Sea during sparse sea ice cover. Marine Ecology Progress Series 468:1-13. http://dx.doi.org/10.3354/ meps 10057

Johnson, J. S., E. D. Nobmann, E. Asay, and A. P. Lanier. 2009. Dietary intake of Alaska Native people in two regions and implications for health: the Alaska Native dietary and subsistence food assessment project. International Journal of Circumpolar Health 68(2):109-122. http://dx.doi.org/10.3402/ijch.v68i2.18320

Joly, K., R. R. Jandt, and D. R. Klein. 2009. Decrease of lichens in Arctic ecosystems: the role of wildfire, caribou, reindeer, competition and climate in north-western Alaska. Polar Research 28:433-442. http://dx.doi.org/10.1111/j.1751-8369.2009.00113.x

Joly, K., D. R. Klein, D. L. Verbyla, T. S. Rupp, and F. S. Chapin III. 2011. Linkages between large-scale climate patterns and the dynamics of Arctic caribou populations. Ecography 34 (2):345-352. http://dx.doi.org/10.1111/j.1600-0587.2010.06377.x

Kassam, K.-A. S., and The Wainwright Traditional Council. 2001. Passing on the knowledge. Arctic Institute of North America, Calgary, Alberta, Canada.

Keeney, R. L. 1982. Decision analysis: an overview. Operations Research 30(5):803-838. http://dx.doi.org/10.1287/opre.30.5.803

Kofinas, G., S. BurnSilver, J. Magdanz, R. Stotts, and M. Okada. 2016. Subsistence sharing networks and cooperation: Kaktovik, Wainwright, and Venetie, Alaska. BOEM Report 2015-023, School of Natural Resources and Extension, University of Alaska Fairbanks, Fairbanks, Alaska, USA.

Kruse, J. A., R. G. White, H. E. Epstein, B. Archie, M. Berman, S. R. Braund, F. S. Chapin III, J. Charlie Jr, C. J. Daniel, J. Eamer, N. Flanders, B. Griffith, S. Haley, L. Huskey, B. Joseph, D. R. Klein, G. P. Kofinas, S. M. Martin, S. M. Murphy, W. Nebesky, C. Nicolson, D. E. Russell, J. Tetlichi, A. Tussing, M. D. Walker, and O. R. Young. 2004. Modeling sustainability of Arctic communities: an interdisciplinary collaboration of researchers and local knowledge holders. Ecosystems 7(8):815-828. http://dx. doi.org/10.1007/s10021-004-0008-Z

Laidre, K. L., I. Stirling, L. F. Lowry, Ø. Wiig, M. P. HeideJørgensen, and S. H. Ferguson. 2008. Quantifying the sensitivity of arctic marine mammals to climate-induced habitat change. Ecological Applications 18(2):S97-S125. http://dx.doi. org/10.1890/06-0546.1

Lantuit, H., and W. H. Pollard. 2008. Fifty years of coastal erosion and retrogressive thaw slump activity on Herschel Island, southern Beaufort Sea, Yukon Territory, Canada. Geomorphology 95:84-102. http://dx.doi.org/10.1016/j.geomorph.2006.07.040

Loe, L. E., B. B. Hansen, A. Stien, S. D. Albon, R. Bischof, A. Carlsson, R. J. Irvine, M. Meland, I. M. Rivrud, E. Ropstad, V. Veiberg, and A. Mysterud. 2016. Behavioral buffering of extreme weather events in a high-Arctic herbivore. Ecosphere 7(6):e01374. http://dx.doi.org/10.1002/ecs2.1374

Logerwell, E., M. Busby, C. Carothers, S. Cotton, J. DuffyAnderson, E. Farley, P. Goddard, R. Heintz, B. Holladay, J. Horne, S. Johnson, B. Lauth, L. Moulton, D. Neff, B. Norcross, S. Parker-Stetter, J. Seigle, and T. Sformo. 2015. Fish communities across a spectrum of habitats in the western Beaufort Sea and 
Chukchi Sea. Progress in Oceanography 136:115-132. http://dx. doi.org/10.1016/j.pocean.2015.05.013

Lovvorn, J. R., J. M. Grebmeier, L. W. Cooper, J. K Bump, and S. E. Richman. 2009. Modeling marine protected areas for threatened eiders in a climatically changing Bering Sea. Ecological Applications 19:1596-1613. http://dx.doi.org/10.1890/08-1193.1

Martin, J., P. L. Fackler, J. D. Nichols, M. C. Runge, C. L. McIntyre, B. L. Lubow, M. C. McCluskie, and J. A. Schmutz. 2011. An adaptive-management framework for optimal control of hiking near Golden Eagle nests in Denali National Park. Conservation Biology 25(2):316-323. http://dx.doi.org/10.1111/ j.1523-1739.2010.01644.x

Metcalf, V., and M. Robards. 2008. Sustaining a healthy human - walrus relationship in a dynamic environment: challenges for comanagement. Ecological Applications 18(2):148-156. http://dx. doi.org/10.1890/06-0642.1

Nelson, D. R., W. N. Adger, and K. Brown. 2007. Adaptation to environmental change: contributions of a resilience framework. Annual Review of Environment and Resources 32:395-419. http:// dx.doi.org/10.1146/annurev.energy.32.051807.090348

Nelson, G., J. Rosegrant, R. Robertson, T. Sulser, T. Zhu, C. Ringler, S. Msangi, A. Palazzo, B. M. R. Magalhaes, M. Valmonte-Santos, M. Ewing, and D. Lee. 2009. Climate change: impact on agriculture and costs of adaptation. International Food Policy Research Institute (IFPRI). Washington, D.C., USA.

Newton, J., C. D. J. Paci, and A. Ogden. 2005. Climate change and natural hazards in northern Canada: integrating indigenous perspectives with government policy. Mitigation and Adaptation Strategies for Global Change 10:541-571. http://dx.doi. org/10.1007/s11027-005-0060-9

Nichols, J. D., M. D. Koneff, P. J. Heglund, M. G. Knutson, M. E. Seamans, J. E. Lyons, J. M. Morton, M. T. Jones, G. S. Boomer, and B. K. Williams. 2011. Climate change, uncertainty, and natural resource management. Journal of Wildlife Management 75(1):6-18. http://dx.doi.org/10.1002/jwmg.33

Ogden, A. E., and J. L. Innes. 2009. Application of structured decision making to an assessment of climate change vulnerabilities and adaptation options for sustainable forest management. Ecology and Society 14(1):11. http://dx.doi. org/10.5751/ES-02771-140111

Ohlson, D. W., G. A. McKinnon, and K. G. Hirsch. 2005. A structured decision-making approach to climate change adaptation in the forest sector. Forestry Chronicle 81(1):97-103. http://dx.doi.org/10.5558/tfc81097-1

Overeem, I., R. S. Anderson, C. W. Wobus, G. D. Clow, F. E. Urban, and N. Matell. 2011. Sea ice loss enhances wave action at the Arctic coast. Geophysical Research Letters 38(17):1-6. http:// dx.doi.org/10.1029/2011GL048681

Parrett, L. 2016. Western Arctic caribou herd update. Alaska Fish \& Wildlife News September. [online] URL: http://www.adfg. alaska.gov/index.cfm?adfg=wildlifenews. view article\&articles $\mathrm{id}=794$

Patt, A., M. Tadross, P. Nussbaumer, K. Asante, M. Metzger, J. Rafael, A. Goujon, and G. Brundrit. 2010. Estimating leastdeveloped countries' vulnerability to climate related extreme events over the next 50 years. Proceedings of the National Academy of Sciences 107:1333-1337. http://dx.doi.org/10.1073/pnas.0910253107

Post, E., and M. Forchhammer. 2008. Climate change reduces reproductive success of an Arctic herbivore through trophic mismatch. Philosophical Transactions of the Royal Society of London. Series B, Biological sciences 363(1501):2369-2375. http:// dx.doi.org/10.1098/rstb.2007.2207

Rennert, K. J., G. Roe, J. Putkonen, and C. M. Bitz. 2009. Soil thermal and ecological impacts of rain on snow events in the circumpolar arctic. Journal of Climate 22(9):2302-2315. http://dx. doi.org/10.1175/2008JCLI2117.1

Reynolds, J., D. Wetzel, and T. O'Hara. 2006. Human health implications of omega-3 and omega- 6 fatty acids in blubber of the bowhead whale (Balaena mysticetus). Arctic 59:155-164.

Runge, M. C., S. J. Converse, and J. E. Lyons. 2011. Which uncertainty? Using expert elicitation and expected value of information to design an adaptive program. Biological Conservation 144(4):1214-1223. http://dx.doi.org/10.1016/j. biocon.2010.12.020

Smit, B., and J. Wandel. 2006. Adaptation, adaptive capacity, and vulnerability. Global Environmental Change 16:282-292. http://dx. doi.org/10.1016/j.gloenvcha.2006.03.008

Sokolov, A. A., N. A. Sokolova, R. A. Ims, L. Brucker, and D. Ehrich. 2016. Emergent rainy winter warm spells may promote boreal predator expansion into the Arctic. Arctic 69(2):1-9. http:// dx.doi.org/10.14430/arctic4559

Statham, S., J. Ford, L. Berrang-Ford, and M.-P. Lardeau. 2015. Anomalous climatic conditions during winter 2010-2011 and vulnerability of the traditional Inuit food system in Iqaluit, Nunavut. Polar Record 51(3):301-317. http://dx.doi.org/10.1017/ $\underline{\mathrm{S} 0032247414000151}$

Stewart, B. C., K. E. Kunkel, L. E. Stevens, L. Sun, and J. E. Walsh. 2013. Regional climate trends and scenarios for the US National Climate Assessment: Part 7 Climate of Alaska. NOAA Technical Report NESDIS 142-7. National Oceanic and Atmospheric Administration, U.S. Department of Commerce, Washington, D.C., USA.

Stroeve, J., M. M. Holland, W. Meier, T. Scambos, and M. Serreze. 2007. Arctic sea ice decline: faster than forecast. Geophysical Research Letters 34(9):1-5. http://dx.doi.org/10.1029/2007GL029703

Sturm, M., C. Racine, and K. Tape. 2001. Increasing shrub abundance in the Arctic. Nature 411:546-547. http://dx.doi. org/10.1038/35079180

Udevitz, M. S., R. L. Taylor, J. L. Garlich-Miller, L. T. Quakenbush, and J. A. Snyder. 2013. Potential population-level effects of increased haulout-related mortality of Pacific walrus calves. Polar Biology 36(2):291-298. http://dx.doi.org/10.1007/ $\underline{\mathrm{s} 00300-012-1259-3}$

U.S. Census Bureau. 2017. Population Division. Annual estimates of the resident population: April 1, 2010 to July 1, 2017. U.S. Census Bureau, Washington, D.C., USA. [online] URL: https:// factfinder.census.gov/faces/nav/jsf/pages/community facts.xhtml? $\underline{\mathrm{src}=\mathrm{bkmk}}$ 
Vermaire, J. C., M. F. J. Pisaric, J. R. Thienpont, C. J. C. Mustaphi, S. V Kokelj, and J. P. Smol. 2013. Arctic climate warming and sea ice declines lead to increased storm surge activity. Geophysical Research Letters 40:1386-1390. http://dx.doi.org/10.1002/ grl.50191

Vors, L. S., and M. S. Boyce. 2009. Global declines of caribou and reindeer. Global Change Biology 15(11):2626-2633. http://dx. doi.org/10.1111/j.1365-2486.2009.01974.X

Wainwright Trilateral Committee. 2014. Wainwright Comprehensive Plan. Report prepared for the North Slope Borough. UMIAQ Environmental and Olgoonik, Anchorage, Alaska, USA.

Wang, M., and J. E. Overland. 2015. Projected future duration of the sea-ice-free season in the Alaskan Arctic. Progress in Oceanography 136:50-59. http://dx.doi.org/10.1016/j.pocean.2015.01.001

Western Regional Climate Center (WRCC). 2016. Wainwright, Alaska: period of record monthly climate summary. WRCC, Reno, Nevada, USA. [online] URL: http://www.wrcc.dri.edu/cgi-bin/ cliMAIN.pl?akwain

Wexler, L., L. Joule, J. Garoutte, J. Mazziotti, and K. Hopper. 2014. "Being responsible, respectful, trying to keep the tradition alive:" cultural resilience and growing up in an Alaska Native community. Transcultural Psychiatry 51(5):693-712. http://dx. doi.org/10.1177/1363461513495085

Yohe, G., and R. S. J. Tol. 2002. Indicators for social and economic coping capacity - moving toward a working definition of adaptive capacity Global Environmental Change 12:25-40. http://dx.doi. org/10.1016/S0959-3780(01)00026-7 
Appendix 1. Materials used in workshops to elicit Traditional Ecological Knowledge including open-ended questions to facilitate discussion, a Structured Decision Analysis consequence table, and multiple-choice surveys completed by individual participants.

\section{Workshop 1 - 27-28 January, 2015}

Open-ended questions (after concepts of SDA had been introduced)

1. What is the reason people live and stay in Wainwright?

2. What factors affect the ability of people to live and stay in Wainwright?

3. What topics would you like to focus on for this decision-making framework, ie what issues or problems relating to the ability to stay in Wainwright are important to you?

\section{Workshop 2 - 28 July, 2015}

Open-ended question (after a brief refresher on SDA and topics covered during workshop 1)

1. We are providing a tool for decision-making, and in the previous workshop you identified some broad topics that are important to the community of Wainwright (for example maintaining the subsistence way of life while allowing for development). If possible, we would like the group to identify three specific issues to focus on for this exercise.

\section{Follow-up discussion with two participants, 19 November, 2015}

Open-ended questions

1. Please take a look at these influence diagrams (pasted below, as developed by the authors following discussions during Workshop 2) and tell us if they seem accurate to you. 
Figure A1.1. Model of the caribou subsistence system in Wainwright, Alaska

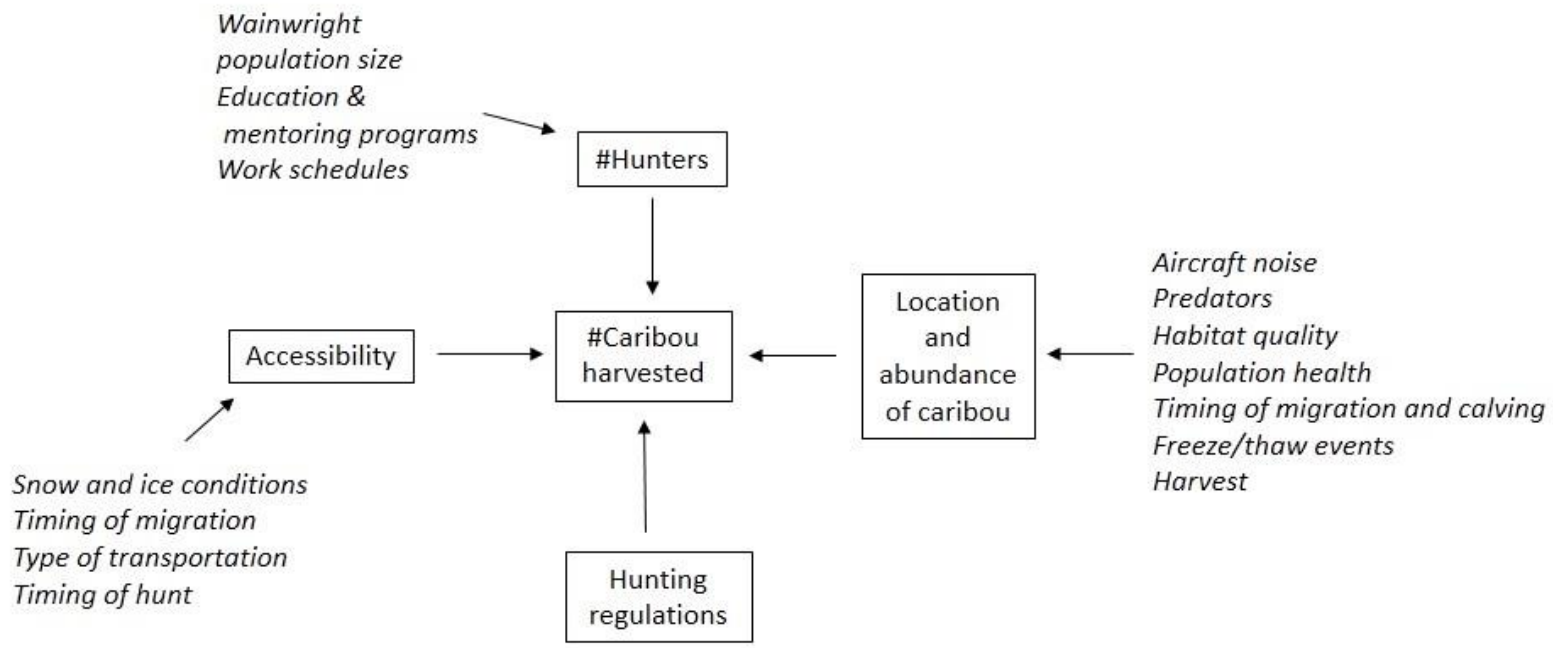

Figure A1.2. Model of bowhead whale subsistence system in Wainwright, Alaska

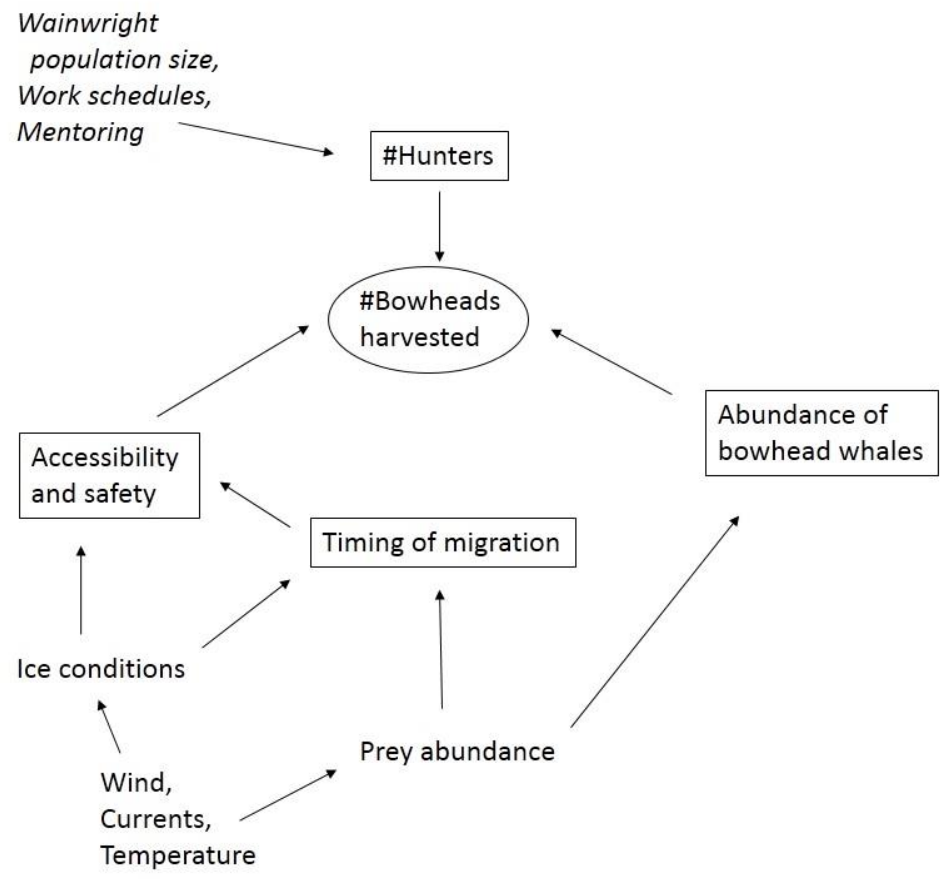


Figure A1.3. Model of walrus subsistence system in Wainwright, Alaska

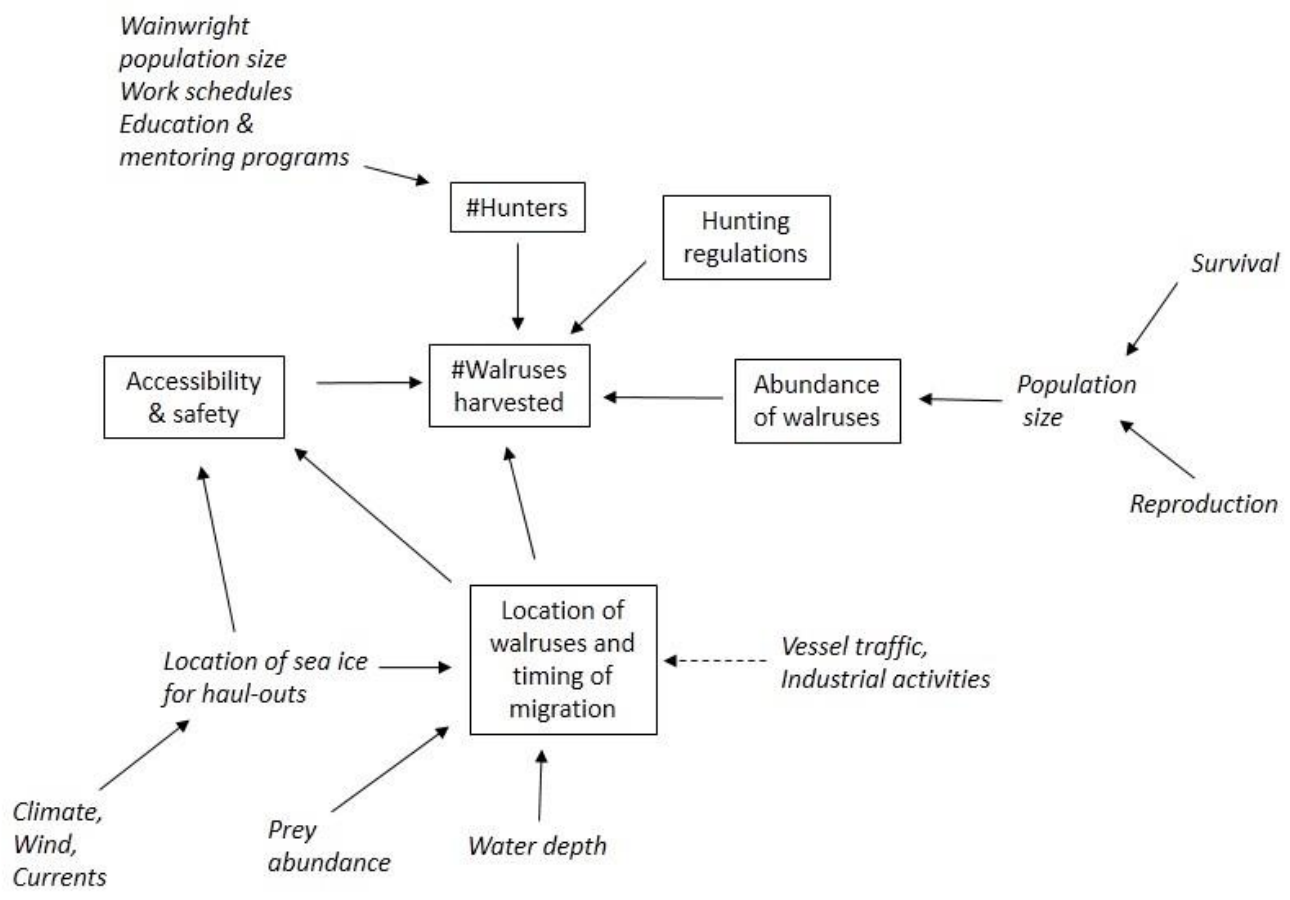

Figure A1.4. Model of bearded seal subsistence system in Wainwright, Alaska

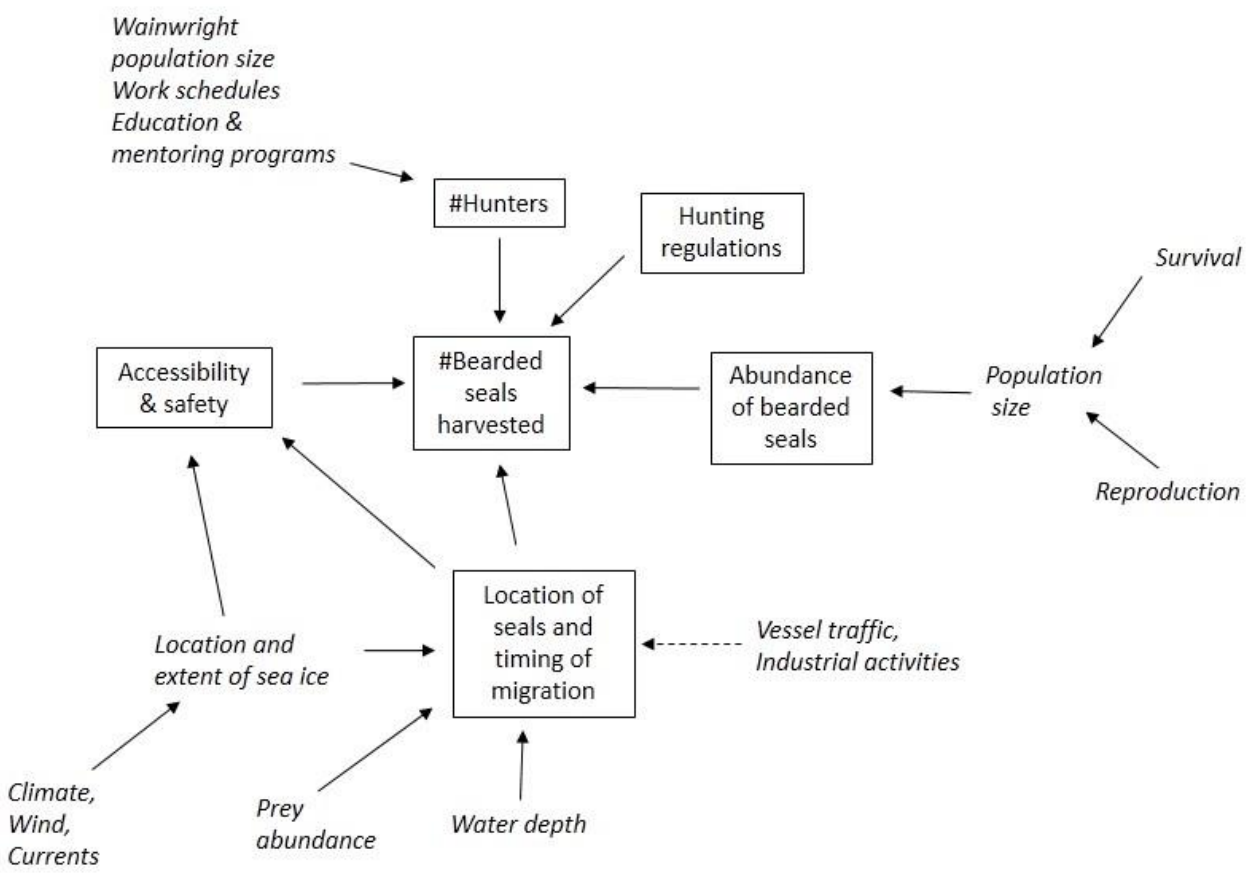


2. How do you anticipate that climate change will affect hunting activities for each of the above species?

3. What would be a good way to survey peoples' attitudes about what limits hunter access to these resources?

4. What strategies could the community put in place to enhance hunter safety in Wainwright? What ranking system would make sense to evaluate these strategies? 
Workshop 3 - 3-4 March, 2016

Table A1.1. Structured Decision Analysis consequence table for hunter safety strategies. Participants evaluated each strategy based on its ability to meet the objectives. This consequence table was completed by the group during workshop 3 .

\begin{tabular}{|c|c|c|c|c|c|c|c|c|c|c|}
\hline Objective & $\begin{array}{l}\text { Weight } \\
(\%)\end{array}$ & $\begin{array}{l}\text { Performance } \\
\text { measure }\end{array}$ & $\begin{array}{l}\text { Safety } \\
\text { equipment } \\
\text { sharing }\end{array}$ & $\begin{array}{l}\text { inReach } \\
\text { group } \\
\text { discount } \\
\text { program }\end{array}$ & $\begin{array}{l}\text { SPOT } \\
\text { group } \\
\text { discount } \\
\text { program }\end{array}$ & $\begin{array}{l}\text { Financial } \\
\text { aid for } \\
\text { capital } \\
\text { equipment } \\
\text { (eg. boats) }\end{array}$ & $\begin{array}{l}\text { Safety } \\
\text { works- } \\
\text { hops }\end{array}$ & $\begin{array}{l}\text { Hunter } \\
\text { meeting } \\
\text { place }\end{array}$ & $\begin{array}{l}\text { Docking } \\
\text { facility }\end{array}$ & $\begin{array}{l}\text { Search } \\
\text { and } \\
\text { rescue } \\
\text { boats }\end{array}$ \\
\hline $\begin{array}{l}\text { Prevent } \\
\text { Accidents }\end{array}$ & 40 & $\begin{array}{l}\text { No effect, } \\
\text { low, } \\
\text { moderate, } \\
\text { high }\end{array}$ & & & & & & & & \\
\hline $\begin{array}{l}\text { Successful } \\
\text { rescue }\end{array}$ & 40 & $\begin{array}{l}\text { No effect, } \\
\text { low, } \\
\text { moderate, } \\
\text { high }\end{array}$ & & & & & & & & \\
\hline $\begin{array}{l}\text { Minimize } \\
\text { cost }\end{array}$ & 20 & $\begin{array}{l}\$, \$ \$, \$ \$ \$ \\
\$ \$ \$ \$\end{array}$ & & & & & & & & \\
\hline
\end{tabular}


Multiple choice surveys on the importance of different factors on wildlife health and abundance.

\section{CARIBOU}

1. How important are the following factors in influencing caribou health and abundance?

\begin{tabular}{|c|c|c|c|c|}
\hline & $\begin{array}{c}\text { Very } \\
\text { important }\end{array}$ & $\begin{array}{l}\text { Somewhat } \\
\text { important }\end{array}$ & Not important & Unknown \\
\hline Synchrony of calf birth & 0 & 0 & 0 & 0 \\
\hline Predator abundance & 0 & O & O & O \\
\hline Summer temperature & 0 & 0 & 0 & 0 \\
\hline Summer forage quality & O & 0 & O & 0 \\
\hline $\begin{array}{l}\text { Insect abundance } \\
\text { (mosquitoes, warbles) }\end{array}$ & $\bigcirc$ & $\bigcirc$ & $\bigcirc$ & $\bigcirc$ \\
\hline $\begin{array}{l}\text { Lichen } \\
\text { abundance/accessibility }\end{array}$ & $\bigcirc$ & $\bigcirc$ & $\bigcirc$ & $\bigcirc$ \\
\hline Snow depth and compaction & 0 & 0 & 0 & 0 \\
\hline Winter temperature & 0 & 0 & 0 & 0 \\
\hline $\begin{array}{l}\text { Frequency of freezing } \\
\text { rain/icing events }\end{array}$ & 0 & $\bigcirc$ & 0 & 0 \\
\hline Timing of spring migration & 0 & 0 & 0 & 0 \\
\hline Timing of fall migration & $\bigcirc$ & 0 & O & $\bigcirc$ \\
\hline $\begin{array}{l}\text { Disturbance by humans } \\
\text { (vehicles, aircraft, etc.) }\end{array}$ & $\bigcirc$ & O & $\bigcirc$ & $\bigcirc$ \\
\hline Harvest by hunters & $\bigcirc$ & $\bigcirc$ & O & $\bigcirc$ \\
\hline Other (please explain): & 0 & 0 & 0 & 0 \\
\hline
\end{tabular}


2. How important are the following factors in influencing caribou hunting success?

\begin{tabular}{|c|c|c|c|c|}
\hline & $\begin{array}{c}\text { Very } \\
\text { important }\end{array}$ & $\begin{array}{l}\text { Somewhat } \\
\text { important }\end{array}$ & Not important & Unknown \\
\hline Abundance of caribou & 0 & $\bigcirc$ & $\bigcirc$ & $\bigcirc$ \\
\hline Timing of spring migration & $\bigcirc$ & $\bigcirc$ & $\bigcirc$ & $\bigcirc$ \\
\hline Timing of fall migration & $\bigcirc$ & $\bigcirc$ & $\bigcirc$ & $\bigcirc$ \\
\hline Caribou distance from town & $\bigcirc$ & 0 & $\bigcirc$ & 0 \\
\hline $\begin{array}{l}\text { Disturbance by humans } \\
\text { (vehicles, aircraft, etc.) }\end{array}$ & $\bigcirc$ & $\bigcirc$ & 0 & \\
\hline $\begin{array}{l}\text { Access to hunting } \\
\text { equipment (snow machine, } \\
\text { ATV, etc.) }\end{array}$ & $\bigcirc$ & $\bigcirc$ & & \\
\hline Hunter expertise & $\bigcirc$ & $\bigcirc$ & $\bigcirc$ & $\bigcirc$ \\
\hline Other? Please explain: & & & & \\
\hline
\end{tabular}

\section{BOWHEAD WHALE}

3. How important are the following factors in influencing bowhead whale health and abundance?

\begin{tabular}{|l|c|c|c|c|}
\hline & $\begin{array}{c}\text { Very } \\
\text { important }\end{array}$ & Somewhat important & $\begin{array}{c}\text { Not } \\
\text { important }\end{array}$ & Unknown \\
\hline Extent of sea ice retreat & $\bigcirc$ & 0 & $\bigcirc$ & $\bigcirc$ \\
\hline $\begin{array}{l}\text { Timing of sea ice } \\
\text { breakup }\end{array}$ & $\bigcirc$ & $\bigcirc$ & $\bigcirc$ & $\bigcirc$ \\
\hline $\begin{array}{l}\text { Zooplankton prey } \\
\text { abundance }\end{array}$ & $\bigcirc$ & $\bigcirc$ & $\bigcirc$ & $\bigcirc$ \\
\hline Shipping traffic & $\bigcirc$ & $\bigcirc$ & $\bigcirc$ & $\bigcirc$ \\
\hline Harvest by hunters & $\bigcirc$ & 0 & $\bigcirc$ & $\bigcirc$ \\
\hline Other? Please explain: & $\bigcirc$ & $\bigcirc$ & $\bigcirc$ & $\bigcirc$ \\
\hline
\end{tabular}


4. How important are the following factors in influencing bowhead whale hunting success?

\begin{tabular}{|c|c|c|c|c|}
\hline & $\begin{array}{c}\text { Very } \\
\text { important }\end{array}$ & Somewhat important & $\begin{array}{c}\text { Not } \\
\text { important }\end{array}$ & Unknown \\
\hline Abundance of whales & 0 & $\bigcirc$ & 0 & 0 \\
\hline Timing of migration & 0 & $\bigcirc$ & $\bigcirc$ & $\bigcirc$ \\
\hline $\begin{array}{l}\text { Timing of sea ice } \\
\text { breakup }\end{array}$ & 0 & 0 & $\bigcirc$ & 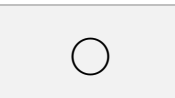 \\
\hline $\begin{array}{l}\text { Duration of breakup } \\
\text { period }\end{array}$ & 0 & 0 & 0 & \\
\hline Shorefast ice thickness & $\bigcirc$ & $\bigcirc$ & $\bigcirc$ & $\bigcirc$ \\
\hline $\begin{array}{l}\text { Distance from shore of } \\
\text { migrating whales }\end{array}$ & 0 & 0 & $\bigcirc$ & ) \\
\hline $\begin{array}{l}\text { Access to hunting } \\
\text { equipment (boats, etc.) }\end{array}$ & $\cap$ & $\Omega$ & $\Omega$ & \\
\hline Hunter expertise & $\bigcirc$ & $\bigcirc$ & $\bigcirc$ & $\bigcirc$ \\
\hline Other? Please explain: & 0 & 0 & 0 & $\bigcirc$ \\
\hline
\end{tabular}

\section{BEARDED SEAL}

5. How important are the following factors in influencing bearded seal health and abundance?

\begin{tabular}{|c|c|c|c|c|}
\hline & $\begin{array}{c}\text { Very } \\
\text { important }\end{array}$ & $\begin{array}{l}\text { Somewhat } \\
\text { important }\end{array}$ & Not important & Unknown \\
\hline Sea ice thickness & O & O & 0 & 0 \\
\hline $\begin{array}{l}\text { Extent of sea ice } \\
\text { retreat }\end{array}$ & 0 & $\bigcirc$ & $\bigcirc$ & 0 \\
\hline $\begin{array}{l}\text { Timing of sea ice } \\
\text { breakup }\end{array}$ & 0 & 0 & 0 & 0 \\
\hline $\begin{array}{l}\text { Benthic prey } \\
\text { abundance (clams, } \\
\text { etc.) }\end{array}$ & 0 & $\bigcirc$ & 0 & 0 \\
\hline Shipping traffic & 0 & $\bigcirc$ & 0 & $\bigcirc$ \\
\hline Harvest by hunters & 0 & $\bigcirc$ & 0 & 0 \\
\hline Other? Please explain: & 0 & 0 & 0 & 0 \\
\hline
\end{tabular}


6. How important are the following factors in influencing bearded seal hunting success?

\begin{tabular}{|c|c|c|c|c|}
\hline & $\begin{array}{c}\text { Very } \\
\text { important }\end{array}$ & $\begin{array}{l}\text { Somewhat } \\
\text { important }\end{array}$ & Not important & Unknown \\
\hline $\begin{array}{l}\text { Abundance of bearded } \\
\text { seals }\end{array}$ & $\bigcirc$ & 0 & 0 & 0 \\
\hline $\begin{array}{l}\text { Timing of spring } \\
\text { migration }\end{array}$ & 0 & 0 & 0 & 0 \\
\hline $\begin{array}{l}\text { Timing of sea ice } \\
\text { breakup }\end{array}$ & 0 & 0 & 0 & 0 \\
\hline $\begin{array}{l}\text { Duration of break-up } \\
\text { period }\end{array}$ & $\bigcirc$ & $\bigcirc$ & $\bigcirc$ & $\bigcirc$ \\
\hline $\begin{array}{l}\text { Location of seals } \\
\text { relative to shoreline }\end{array}$ & 0 & $\bigcirc$ & $C$ & ) \\
\hline $\begin{array}{l}\text { Amount of broken ice } \\
\text { near the shore }\end{array}$ & 0 & 0 & ( & \\
\hline $\begin{array}{l}\text { Access to hunting } \\
\text { equipment (boats, etc.) }\end{array}$ & $\bigcirc$ & $\bigcirc$ & 0 & C \\
\hline Hunter expertise & $\bigcirc$ & $\bigcirc$ & $\bigcirc$ & $\bigcirc$ \\
\hline Other? Please explain: & $\bigcirc$ & $\bigcirc$ & $\bigcirc$ & \\
\hline
\end{tabular}

\section{WALRUS}

7. How important are the following factors in influencing walrus health and abundance?

\begin{tabular}{|c|c|c|c|c|}
\hline & $\begin{array}{c}\text { Very } \\
\text { important }\end{array}$ & $\begin{array}{l}\text { Somewhat } \\
\text { important }\end{array}$ & Not important & Unknown \\
\hline Sea ice thickness & $\bigcirc$ & 0 & 0 & 0 \\
\hline $\begin{array}{l}\text { Extent of sea ice } \\
\text { retreat }\end{array}$ & 0 & $\bigcirc$ & 0 & \\
\hline $\begin{array}{l}\text { Timing of sea ice } \\
\text { breakup }\end{array}$ & 0 & 0 & $\bigcirc$ & \\
\hline $\begin{array}{l}\text { Benthic prey } \\
\text { abundance (clams, } \\
\text { etc.) }\end{array}$ & $\bigcirc$ & 0 & $\bigcirc$ & \\
\hline Shipping traffic & 0 & 0 & $\bigcirc$ & $\bigcirc$ \\
\hline Harvest by hunters & $\bigcirc$ & 0 & $\bigcirc$ & $\bigcirc$ \\
\hline Other? Please explain: & 0 & 0 & $\bigcirc$ & 0 \\
\hline
\end{tabular}


8. How important are the following factors in influencing walrus hunting success?

\begin{tabular}{|c|c|c|c|c|}
\hline & $\begin{array}{c}\text { Very } \\
\text { important }\end{array}$ & $\begin{array}{l}\text { Somewhat } \\
\text { important }\end{array}$ & Not important & Unknown \\
\hline $\begin{array}{l}\text { Abundance of } \\
\text { walruses }\end{array}$ & 0 & 0 & & $\bigcirc$ \\
\hline $\begin{array}{l}\text { Timing of spring } \\
\text { migration }\end{array}$ & $\bigcirc$ & $\bigcirc$ & 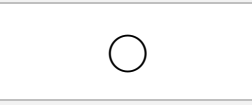 & $\bigcirc$ \\
\hline $\begin{array}{l}\text { Timing of sea ice } \\
\text { breakup }\end{array}$ & $\bigcirc$ & $\bigcirc$ & ) & $\bigcirc$ \\
\hline $\begin{array}{l}\text { Duration of break-up } \\
\text { period }\end{array}$ & $\bigcirc$ & 0 & & $\bigcirc$ \\
\hline $\begin{array}{l}\text { Distance from shore of } \\
\text { migrating walruses }\end{array}$ & 0 & $\Omega$ & & 0 \\
\hline $\begin{array}{l}\text { Amount of broken ice } \\
\text { near shore }\end{array}$ & 0 & 0 & & $\Omega$ \\
\hline $\begin{array}{l}\text { Access to hunting } \\
\text { equipment (boats, etc.) }\end{array}$ & $\bigcirc$ & $\bigcirc$ & $\Omega$ & $\bigcirc$ \\
\hline Hunter expertise & 0 & $\bigcirc$ & $\bigcirc$ & 0 \\
\hline Other? Please explain: & $\bigcirc$ & $\bigcirc$ & $\bigcirc$ & $\bigcirc$ \\
\hline
\end{tabular}


Workshop 4 - 4-5 January, 2017

Multiple choice surveys on dependence of subsistence activities on sea ice and observed changes in availability.

1. How dependent is each subsistence activity on safe ice conditions?

\begin{tabular}{|c|c|c|c|c|}
\hline & High & Medium & Low & Unknown \\
\hline Bowhead whale (spring harvest) & 0 & O & O & O \\
\hline Bowhead whale (fall harvest) & $\mathrm{O}$ & O & 0 & O \\
\hline Beluga & $\bigcirc$ & O & $\bigcirc$ & O \\
\hline Bearded seal & $\bigcirc$ & O & $\mathrm{O}$ & $\bigcirc$ \\
\hline Walrus & $\bigcirc$ & $\bigcirc$ & $\bigcirc$ & $\bigcirc$ \\
\hline Salmon & $\mathrm{O}$ & 0 & $\mathrm{O}$ & O \\
\hline Tomcod & 0 & O & 0 & O \\
\hline Whitefish & 0 & 0 & 0 & $\bigcirc$ \\
\hline Grayling & 0 & 0 & 0 & 0 \\
\hline Smelt & $\mathrm{O}$ & O & O & O \\
\hline Snow goose & 0 & O & 0 & O \\
\hline White-fronted goose & 0 & O & 0 & O \\
\hline Brant goose & $\mathrm{O}$ & O & O & O \\
\hline Sea ducks & $\bigcirc$ & O & $\bigcirc$ & O \\
\hline Caribou & O & O & O & 0 \\
\hline Wild plants, berries & 0 & 0 & 0 & 0 \\
\hline
\end{tabular}


2. How vulnerable is each species to loss of sea ice in the Wainwright area?

\begin{tabular}{|l|l|l|l|l|}
\hline & High & Medium & Low & Unknown \\
\hline Bowhead whale & $\bigcirc$ & $\bigcirc$ & $\bigcirc$ & $\bigcirc$ \\
\hline Beluga & $\bigcirc$ & $\bigcirc$ & $\bigcirc$ & $\bigcirc$ \\
\hline Bearded seal & $\bigcirc$ & $\bigcirc$ & $\bigcirc$ & $\bigcirc$ \\
\hline Walrus & $\bigcirc$ & $\bigcirc$ & $\bigcirc$ & $\bigcirc$ \\
\hline Salmon & $\bigcirc$ & $\bigcirc$ & $\bigcirc$ & $\bigcirc$ \\
\hline Tomcod & $\bigcirc$ & $\bigcirc$ & $\bigcirc$ & $\bigcirc$ \\
\hline Whitefish & $\bigcirc$ & $\bigcirc$ & $\bigcirc$ & $\bigcirc$ \\
\hline Grayling & $\bigcirc$ & $\bigcirc$ & $\bigcirc$ & $\bigcirc$ \\
\hline Smelt & $\bigcirc$ & $\bigcirc$ & $\bigcirc$ & $\bigcirc$ \\
\hline Snow goose & $\bigcirc$ & $\bigcirc$ & $\bigcirc$ & $\bigcirc$ \\
\hline White-fronted goose & $\bigcirc$ & $\bigcirc$ & $\bigcirc$ & $\bigcirc$ \\
\hline Brant goose & $\bigcirc$ & $\bigcirc$ & $\bigcirc$ \\
\hline Sea ducks & $\bigcirc$ & $\bigcirc$ & $\bigcirc$ & $\bigcirc$ \\
\hline Caribou & $\bigcirc$ & $\bigcirc$ & $\bigcirc$ & $\bigcirc$ \\
\hline Wild plants, berries & $\bigcirc$ & $\bigcirc$ & $\bigcirc$ & $\bigcirc$ \\
\hline
\end{tabular}


3. Have you observed a change in each species' availability over the past decade?

\begin{tabular}{|c|c|c|c|c|c|c|}
\hline & $\begin{array}{l}\text { Strong } \\
\text { decline }\end{array}$ & $\begin{array}{l}\text { Slight } \\
\text { decline }\end{array}$ & $\begin{array}{c}\text { No } \\
\text { change }\end{array}$ & $\begin{array}{c}\text { Slight } \\
\text { increase }\end{array}$ & $\begin{array}{c}\text { Strong } \\
\text { increase }\end{array}$ & Unknown \\
\hline Bowhead whale (spring harvest) & $\bigcirc$ & $\bigcirc$ & O & O & $\bigcirc$ & $\bigcirc$ \\
\hline Bowhead whale (fall harvest) & $\bigcirc$ & $\bigcirc$ & $\bigcirc$ & $\bigcirc$ & $\bigcirc$ & $\bigcirc$ \\
\hline Beluga & O & O & $\bigcirc$ & $\bigcirc$ & $\bigcirc$ & $\bigcirc$ \\
\hline Bearded seal & $\bigcirc$ & $\bigcirc$ & $\bigcirc$ & $\bigcirc$ & 0 & $\bigcirc$ \\
\hline Walrus & 0 & 0 & 0 & 0 & 0 & 0 \\
\hline Salmon & $\bigcirc$ & $\bigcirc$ & $\bigcirc$ & $\bigcirc$ & 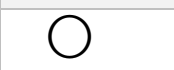 & $\bigcirc$ \\
\hline Tomcod & O & O & $\bigcirc$ & $\bigcirc$ & $\bigcirc$ & $\bigcirc$ \\
\hline Whitefish & $\bigcirc$ & $\bigcirc$ & $\bigcirc$ & $\bigcirc$ & 0 & $\bigcirc$ \\
\hline Grayling & $\bigcirc$ & $\bigcirc$ & $\bigcirc$ & $\bigcirc$ & 0 & 0 \\
\hline Smelt & $\bigcirc$ & $\bigcirc$ & $\bigcirc$ & O & 0 & $\bigcirc$ \\
\hline Snow goose & $\bigcirc$ & $\mathrm{O}$ & $\bigcirc$ & $\bigcirc$ & $\mathrm{O}$ & $\bigcirc$ \\
\hline White-fronted goose & $\bigcirc$ & $\bigcirc$ & $\bigcirc$ & $\bigcirc$ & 0 & $\bigcirc$ \\
\hline Brant goose & $\bigcirc$ & O & O & 0 & 0 & $\bigcirc$ \\
\hline Sea ducks & $\bigcirc$ & $\bigcirc$ & $\bigcirc$ & $\bigcirc$ & $\bigcirc$ & $\bigcirc$ \\
\hline Caribou & $\bigcirc$ & 0 & $\bigcirc$ & 0 & 0 & $\bigcirc$ \\
\hline Wild plants, berries & 0 & $\bigcirc$ & $\bigcirc$ & 0 & 0 & 0 \\
\hline
\end{tabular}


Open-ended questions

1. What kind of products would be useful for the community of Wainwright? Examples of products are a presentation to the Trilateral committee and/or Alak school, a visually appealing report available to all community members (provided examples of such reports).

2. How could Structured Decision Analysis complement traditional decision making in Wainwright?

3. Did you find the SDA process helpful? If so, how? 
Appendix 2. Supplemental data on the perceived importance of factors influencing health, abundance, and hunting success of key subsistence species in Wainwright, Alaska

Table A2.1. Results of surveys assessing factors influencing health, abundance and hunting success of caribou, bowhead whales, walruses, and bearded seals harvested in Wainwright, Alaska. Numbers reflect the proportion of workshop participants who considered each factor as very important, somewhat important, or not important. Standard errors of proportions are also shown.

\begin{tabular}{|c|c|c|c|c|c|c|c|c|c|c|}
\hline \multirow[b]{2}{*}{ Species } & \multirow[b]{2}{*}{$\begin{array}{l}\text { Influence } \\
\text { on }\end{array}$} & \multirow[b]{2}{*}{ Factor } & \multicolumn{2}{|c|}{ Very important } & \multicolumn{2}{|c|}{ Somewhat important } & \multicolumn{2}{|c|}{ Not important } & \multicolumn{2}{|c|}{$\begin{array}{c}\text { Unknown/ No } \\
\text { response }\end{array}$} \\
\hline & & & Proportion & $\begin{array}{l}\text { Standard } \\
\text { Error }\end{array}$ & Proportion & $\begin{array}{l}\text { Standard } \\
\text { Error }\end{array}$ & Proportion & $\begin{array}{l}\text { Standard } \\
\text { Error }\end{array}$ & Proportion & $\begin{array}{l}\text { Standard } \\
\text { Error }\end{array}$ \\
\hline \multirow[t]{13}{*}{ Caribou } & \multirow{13}{*}{$\begin{array}{l}\text { Health \& } \\
\text { abundance }\end{array}$} & Synchrony of calf birth & 0.78 & 0.14 & 0.00 & 0.00 & 0.00 & 0.00 & 0.22 & 0.14 \\
\hline & & Predator abundance & 0.56 & 0.17 & 0.44 & 0.17 & 0.00 & 0.00 & 0.00 & 0.00 \\
\hline & & Summer temperature & 0.44 & 0.17 & 0.33 & 0.16 & 0.00 & 0.00 & 0.22 & 0.14 \\
\hline & & Summer forage quality & 0.78 & 0.14 & 0.11 & 0.10 & 0.00 & 0.00 & 0.11 & 0.10 \\
\hline & & Insect abundance & 0.25 & 0.15 & 0.63 & 0.17 & 0.00 & 0.00 & 0.13 & 0.12 \\
\hline & & Lichen abundance/accessibility & 0.67 & 0.16 & 0.22 & 0.14 & 0.00 & 0.00 & 0.11 & 0.10 \\
\hline & & Snow depth and compaction & 0.78 & 0.14 & 0.11 & 0.10 & 0.00 & 0.00 & 0.11 & 0.10 \\
\hline & & Winter temperature & 0.44 & 0.17 & 0.44 & 0.17 & 0.00 & 0.00 & 0.11 & 0.10 \\
\hline & & $\begin{array}{l}\text { Frequency of freezing rain/icing } \\
\text { events }\end{array}$ & 0.78 & 0.14 & 0.00 & 0.00 & 0.00 & 0.00 & 0.22 & 0.14 \\
\hline & & Timing of spring migration & 0.22 & 0.14 & 0.67 & 0.16 & 0.00 & 0.00 & 0.11 & 0.10 \\
\hline & & Timing of fall migration & 0.13 & 0.12 & 0.63 & 0.17 & 0.00 & 0.00 & 0.25 & 0.15 \\
\hline & & $\begin{array}{l}\text { Disturbance by humans (vehicles, } \\
\text { aircraft) }\end{array}$ & 0.33 & 0.16 & 0.44 & 0.17 & 0.22 & 0.14 & 0.00 & 0.00 \\
\hline & & Harvest by hunters & 0.22 & 0.14 & 0.56 & 0.17 & 0.22 & 0.14 & 0.00 & 0.00 \\
\hline \multirow[t]{3}{*}{ Caribou } & \multirow{3}{*}{$\begin{array}{l}\text { Hunting } \\
\text { success }\end{array}$} & Abundance of caribou & 0.67 & 0.16 & 0.33 & 0.16 & 0.00 & 0.00 & 0.00 & 0.00 \\
\hline & & Timing of spring migration & 0.00 & 0.00 & 0.78 & 0.14 & 0.11 & 0.10 & 0.11 & 0.10 \\
\hline & & Timing of fall migration & 0.67 & 0.16 & 0.22 & 0.14 & 0.00 & 0.00 & 0.11 & 0.10 \\
\hline
\end{tabular}




\begin{tabular}{|c|c|c|c|c|c|c|c|c|c|c|}
\hline \multirow[b]{2}{*}{ Species } & \multirow[b]{2}{*}{$\begin{array}{l}\text { Influence } \\
\text { on }\end{array}$} & \multirow[b]{2}{*}{ Factor } & \multicolumn{2}{|c|}{ Very important } & \multicolumn{2}{|c|}{ Somewhat important } & \multicolumn{2}{|c|}{ Not important } & \multicolumn{2}{|c|}{$\begin{array}{l}\text { Unknown/ No } \\
\text { response }\end{array}$} \\
\hline & & & Proportion & $\begin{array}{c}\text { Standard } \\
\text { Error }\end{array}$ & Proportion & $\begin{array}{c}\text { Standard } \\
\text { Error }\end{array}$ & Proportion & $\begin{array}{l}\text { Standard } \\
\text { Error }\end{array}$ & Proportion & $\begin{array}{l}\text { Standard } \\
\text { Error }\end{array}$ \\
\hline \multirow[t]{3}{*}{ Caribou } & \multirow{9}{*}{$\begin{array}{l}\text { Health \& } \\
\text { abundance }\end{array}$} & Access to hunting equipment & 0.67 & 0.16 & 0.11 & 0.10 & 0.11 & 0.10 & 0.11 & 0.10 \\
\hline & & Hunter expertise & 0.33 & 0.16 & 0.44 & 0.17 & 0.11 & 0.10 & 0.11 & 0.10 \\
\hline & & Price of fuel & 0.83 & 0.15 & 0.00 & 0.00 & 0.00 & 0.00 & 0.17 & 0.15 \\
\hline \multirow{15}{*}{$\begin{array}{l}\text { Bowhead } \\
\text { whale }\end{array}$} & & Extent of sea ice retreat & 0.33 & 0.16 & 0.33 & 0.16 & 0.11 & 0.10 & 0.22 & 0.14 \\
\hline & & Timing of sea ice breakup & 0.33 & 0.16 & 0.56 & 0.17 & 0.00 & 0.00 & 0.11 & 0.10 \\
\hline & & Zooplankton prey abundance & 0.78 & 0.14 & 0.11 & 0.10 & 0.00 & 0.00 & 0.11 & 0.10 \\
\hline & & shipping traffic & 0.22 & 0.14 & 0.33 & 0.16 & 0.11 & 0.10 & 0.33 & 0.16 \\
\hline & & harvest by hunters & 0.44 & 0.17 & 0.22 & 0.14 & 0.22 & 0.14 & 0.11 & 0.10 \\
\hline & & Predators (killer whales) & 0.20 & 0.18 & 0.20 & 0.18 & 0.20 & 0.18 & 0.40 & 0.22 \\
\hline & \multirow{9}{*}{$\begin{array}{l}\text { Hunting } \\
\text { success }\end{array}$} & Abundance of whales & 0.75 & 0.15 & 0.13 & 0.12 & 0.13 & 0.12 & 0.00 & 0.00 \\
\hline & & Timing of migration & 1.00 & 0.00 & 0.00 & 0.00 & 0.00 & 0.00 & 0.00 & 0.00 \\
\hline & & Timing of sea ice breakup & 0.88 & 0.12 & 0.13 & 0.12 & 0.00 & 0.00 & 0.00 & 0.00 \\
\hline & & Duration of break up period & 0.50 & 0.18 & 0.38 & 0.17 & 0.00 & 0.00 & 0.13 & 0.12 \\
\hline & & Shorefast ice thickness & 1.00 & 0.00 & 0.00 & 0.00 & 0.00 & 0.00 & 0.00 & 0.00 \\
\hline & & $\begin{array}{l}\text { Distance from shore of migrating } \\
\text { whales }\end{array}$ & 0.63 & 0.17 & 0.25 & 0.15 & 0.13 & 0.12 & 0.00 & 0.00 \\
\hline & & Access to hunting equipment & 0.88 & 0.12 & 0.13 & 0.12 & 0.00 & 0.00 & 0.00 & 0.00 \\
\hline & & Hunter expertise & 0.88 & 0.12 & 0.13 & 0.12 & 0.00 & 0.00 & 0.00 & 0.00 \\
\hline & & Weather (storms etc) & 0.50 & 0.25 & 0.00 & 0.00 & 0.25 & 0.22 & 0.25 & 0.22 \\
\hline
\end{tabular}




\begin{tabular}{|c|c|c|c|c|c|c|c|c|c|c|}
\hline \multirow[b]{2}{*}{ Species } & \multirow[b]{2}{*}{$\begin{array}{l}\text { Influence } \\
\text { on }\end{array}$} & \multirow[b]{2}{*}{ Factor } & \multicolumn{2}{|c|}{ Very important } & \multicolumn{2}{|c|}{ Somewhat important } & \multicolumn{2}{|c|}{ Not important } & \multicolumn{2}{|c|}{ Unknown/ No response } \\
\hline & & & Proportion & $\begin{array}{l}\text { Standard } \\
\text { Error }\end{array}$ & Proportion & $\begin{array}{l}\text { Standard } \\
\text { Error }\end{array}$ & Proportion & $\begin{array}{l}\text { Standard } \\
\text { Error }\end{array}$ & Proportion & $\begin{array}{l}\text { Standard } \\
\text { Error }\end{array}$ \\
\hline \multirow{14}{*}{$\begin{array}{l}\text { Bearded } \\
\text { seal }\end{array}$} & \multirow{6}{*}{$\begin{array}{l}\text { Health \& } \\
\text { abundance }\end{array}$} & Sea Ice thickness & 0.56 & 0.17 & 0.33 & 0.16 & 0.11 & 0.10 & 0.00 & 0.00 \\
\hline & & Extent of sea ice retreat & 0.56 & 0.17 & 0.22 & 0.14 & 0.00 & 0.00 & 0.22 & 0.14 \\
\hline & & Timing of sea ice breakup & 0.44 & 0.17 & 0.44 & 0.17 & 0.00 & 0.00 & 0.11 & 0.10 \\
\hline & & benthic prey abundance & 0.56 & 0.17 & 0.22 & 0.14 & 0.11 & 0.10 & 0.11 & 0.10 \\
\hline & & shipping traffic & 0.13 & 0.12 & 0.38 & 0.17 & 0.13 & 0.12 & 0.38 & 0.17 \\
\hline & & harvest by hunters & 0.44 & 0.17 & 0.44 & 0.17 & 0.11 & 0.10 & 0.00 & 0.00 \\
\hline & \multirow{8}{*}{$\begin{array}{l}\text { Hunting } \\
\text { success }\end{array}$} & Abundance of bearded seals & 0.78 & 0.14 & 0.22 & 0.14 & 0.00 & 0.00 & 0.00 & 0.00 \\
\hline & & Timing of spring migration & 0.78 & 0.14 & 0.22 & 0.14 & 0.00 & 0.00 & 0.00 & 0.00 \\
\hline & & Timing of sea ice breakup & 0.78 & 0.14 & 0.22 & 0.14 & 0.00 & 0.00 & 0.00 & 0.00 \\
\hline & & Duration of break up period & 0.67 & 0.16 & 0.22 & 0.14 & 0.00 & 0.00 & 0.11 & 0.10 \\
\hline & & $\begin{array}{l}\text { Location of seals relative to } \\
\text { shoreline }\end{array}$ & 0.75 & 0.15 & 0.25 & 0.15 & 0.00 & 0.00 & 0.00 & 0.00 \\
\hline & & Amount of broken ice near shore & 0.89 & 0.10 & 0.11 & 0.10 & 0.00 & 0.00 & 0.00 & 0.00 \\
\hline & & Access to hunting equipment & 1.00 & 0.00 & 0.00 & 0.00 & 0.00 & 0.00 & 0.00 & 0.00 \\
\hline & & Hunter expertise & 0.67 & 0.16 & 0.33 & 0.16 & 0.00 & 0.00 & 0.00 & 0.00 \\
\hline \multirow[t]{7}{*}{ Walrus } & \multirow{7}{*}{$\begin{array}{l}\text { Health \& } \\
\text { abundance }\end{array}$} & Sea Ice thickness & 0.75 & 0.15 & 0.25 & 0.15 & 0.00 & 0.00 & 0.00 & 0.00 \\
\hline & & Extent of sea ice retreat & 0.88 & 0.12 & 0.13 & 0.12 & 0.00 & 0.00 & 0.00 & 0.00 \\
\hline & & Timing of sea ice breakup & 0.38 & 0.17 & 0.50 & 0.18 & 0.00 & 0.00 & 0.13 & 0.12 \\
\hline & & Benthic prey abundance & 0.63 & 0.17 & 0.25 & 0.15 & 0.00 & 0.00 & 0.13 & 0.12 \\
\hline & & Shipping traffic & 0.25 & 0.15 & 0.13 & 0.12 & 0.25 & 0.15 & 0.38 & 0.17 \\
\hline & & Harvest by hunters & 0.38 & 0.17 & 0.50 & 0.18 & 0.13 & 0.12 & 0.00 & 0.00 \\
\hline & & Haulout disturbance & 0.67 & 0.27 & 0.33 & 0.27 & 0.00 & 0.00 & 0.00 & 0.00 \\
\hline
\end{tabular}




\begin{tabular}{|c|c|c|c|c|c|c|c|c|c|c|}
\hline \multirow[b]{2}{*}{ Species } & \multirow[b]{2}{*}{$\begin{array}{l}\text { Influence } \\
\text { on }\end{array}$} & \multirow[b]{2}{*}{ Factor } & \multicolumn{2}{|c|}{ Very important } & \multicolumn{2}{|c|}{ Somewhat important } & \multicolumn{2}{|c|}{ Not important } & \multicolumn{2}{|c|}{$\begin{array}{c}\text { Unknown/ No } \\
\text { response }\end{array}$} \\
\hline & & & Proportion & $\begin{array}{c}\text { Standard } \\
\text { Error }\end{array}$ & Proportion & $\begin{array}{c}\text { Standard } \\
\text { Error }\end{array}$ & Proportion & $\begin{array}{l}\text { Standard } \\
\text { Error }\end{array}$ & Proportion & $\begin{array}{l}\text { Standard } \\
\text { Error }\end{array}$ \\
\hline \multirow[t]{8}{*}{ Walrus } & \multirow{8}{*}{$\begin{array}{l}\text { Hunting } \\
\text { success }\end{array}$} & Abundance of walruses & 0.89 & 0.10 & 0.11 & 0.10 & 0.00 & 0.00 & 0.00 & 0.00 \\
\hline & & Timing of spring migration & 0.50 & 0.18 & 0.25 & 0.15 & 0.13 & 0.12 & 0.13 & 0.12 \\
\hline & & Timing of sea ice breakup & 0.63 & 0.17 & 0.25 & 0.15 & 0.13 & 0.12 & 0.00 & 0.00 \\
\hline & & Duration of break up period & 0.50 & 0.18 & 0.38 & 0.17 & 0.13 & 0.12 & 0.00 & 0.00 \\
\hline & & $\begin{array}{l}\text { Distance from shore of migrating } \\
\text { walruses }\end{array}$ & 1.00 & 0.00 & 0.00 & 0.00 & 0.00 & 0.00 & 0.00 & 0.00 \\
\hline & & Amount of broken ice near shore & 1.00 & 0.00 & 0.00 & 0.00 & 0.00 & 0.00 & 0.00 & 0.00 \\
\hline & & Access to hunting equipment & 0.88 & 0.12 & 0.13 & 0.12 & 0.00 & 0.00 & 0.00 & 0.00 \\
\hline & & Hunter expertise & 0.75 & 0.15 & 0.25 & 0.15 & 0.00 & 0.00 & 0.00 & 0.00 \\
\hline
\end{tabular}

